\title{
TABLETS FROM THE SIPPAR LIBRARY XIII ENUTMA ANU ELLIL XX
}

\author{
By F. N. H. AL-RAWI and A. R. GEORGE*
}

\begin{abstract}
Introduction
The Sippar Library tablet IM 124485 is a new source for Tablet XX of Enūma Anu Ellil (EAE), the great compilation of Babylonian celestial and meteorological omens. ${ }^{1}$ The twentieth tablet of the series, which deals principally with lunar eclipses on the fourteenth day of each month of the year, was edited by Francesca Rochberg in 1988 along with all the other tablets of lunar-eclipse omens in EAE (Rochberg-Halton 1988: Chapter 10). Rochberg was unable to report the whole text of her MS M =ND 4357, a Neo-Assyrian tablet from the library of the temple of Nabû at Kalah; it can now be consulted as CTN IV 5 (Wiseman and Black 1996: Pls. 5-6, 145), though the copy of the reverse is inadequate. In addition a Late Babylonian exemplar of a further commentary, written in the time of Philip Arrhidaeus for the scholar Iqiša of Uruk, has come to light in W23300 (now IM 75990), published as Uruk IV 162 (von Weiher 1993: 103-5, 186). Despite these additions to knowledge, some of the text of $E A E \mathrm{XX}$ remained poorly enough preserved to make the discovery of a new manuscript very welcome.

The new tablet allows seven sections of the text of $E A E \mathrm{XX}$ to be reconstructed in full, and our understanding of the technical terminology refined as a consequence. The chief interest of this tablet of $E A E$ emerges more clearly than before. The common denominator of the twelve lunareclipse omens of EAE XX is eclipses that, at least notionally, set in "above" and clear "below", as observed in 1.66 of the tablet published here. However, the observed phenomena that especially distinguish the protases of $E A E \mathrm{XX}$ from those of other calendrical lunar-eclipse tablets appear to be particular to partial eclipses. The progress of the eclipse to a point at which the disk is half eclipsed (imšul) or more (eli mašăli illik) is explicitly recorded on six occasions (\$§I.2, IV, V, VII, VIII, IX). The portents relate either to the moon's "emblem" (šurinnu), a term that signifies the moon in eclipse (\$\$I.1, IV), ${ }^{2}$ to its "horns" (qarnu), i.e. the cusps of the partially eclipsed disk $(\S \S \mathrm{VIII}, \mathrm{IX}, \mathrm{X}, \mathrm{XI}, \mathrm{XII})$, or to both $(\S \S \mathrm{V}, \mathrm{VII})$. It seems that what the compiler of $E A E \mathrm{XX}$ considered most portentous were the appearance, behaviour and other aspects of the lunar disk while the moon was half, or more than half, eclipsed.

Tablets XX and XXI of Enüma Anu Ellil are characterized by long apodoses on ostensibly historical topics, predicting the military and political fortunes of the cities of Babylonia (Akkade, Ur, Babylon, Borsippa, Mutabal, Dilbat, Eridu, Dēr, Ešnunna), of Babylonia as a whole (called Akkad) and of foreign nations such as Assyria (called Subartu), Gutium, Amurru, Elam, Anšan, Umman-manda and Dilmun. These apodoses elicit different responses from scholars of different disciplines. Historians of astronomy and scientists interested in ancient Mesopotamian astronomical data have used them as evidence for determining the chronology of the Old Akkadian and Ur III periods: prominent here are Johann Schaumberger $(1949,1954-6)$ and more recently Peter
\end{abstract}

\footnotetext{
* Al-Rawi's work on the publication of the Tablets from the Sippar Library in Iraq 52 and subsequent issues has been aided by the generosity of the British School of Archaeology in Iraq. His contribution to the present article was the cuneiform copies, photographs and transliteration of IM 124485; George wrote the introduction, transiation, textual notes and commentary. Both authors thank Dr Frances Reynolds for expertly collating the commentary tablet IM 75990 in Baghdad in September 1998, and are grateful to Professor Hermann Hunger for alerting us to errors. Those that remain are our responsibility.

${ }^{1}$ For surveys of the contents of the series Enüma Anu Ellil and associated scholia see recently Koch-Westenholz 1995: 76-93, Hunger and Pingree 1999: 12-22, Reiner 1999, Brown 2000: 254-6, and Rochberg 2004: 66-78.

${ }^{2} \mathrm{On}$ surinnu as a technical term in celestial observation
}

for the "crescent shaped appearance of an eclipsed moon" see Rochberg-Halton 1988: 177, with further discussion on p. $62 \mathrm{fn} .147$. The newly available LB commentary Uruk IV 162 adds to our knowledge with this passage of explanation (obv. 4-6, coll. F. Reynolds): šu-ri-in-ni : qar-nu : MIN : sal$m u$ šá libbi(šà) sin(30) : šá-niš ina šu-ri-in-šú dili-pát ana libbi(šà) $30 \bar{r} r u b\left(\mathrm{ku}_{4}\right):$ šu-ri-in-ni: i-da-tum ana attalêe (AN.MI) "emblem" = horn, ditto = the figure inside the moon; alternatively, (in a protasis like) "(If ) through its "emblem" Venus enters the moon', 'emblem' = portents for an eclipse". The gist of this is that surinnu refers essentially to the ominous parts of the moon in eclipse, both its cusps ("horns") and its face. The passage should be added to the evidence for the Babylonian "man in the moon", for which see Beaulieu 1999. 
Huber (e.g. 1987, 1999-2000, 2000) and, for the Ur III period only, V. G. Gurzadyan (Gasche et al. 1998: 74-6, Gurzadyan 2000). These scholars work on the assumption that omen apodoses in EAE XX and XXI signalling the downfall of kings of Akkade and Ur allude to the ends of particular kings of the Sargonic and Ur III dynasties, and seek to match these historical events with computed occurrences of the lunar-eclipse phenomena described in the respective protases. No consensus has yet emerged, however, in what has been a vigorous debate (see also Koch 1998).

Assyriologists, who are more critically aware of the history of the cuneiform tradition and the evolution of the great omen compilations such as $E A E$, know better the shortcomings and limitations of the material, and remain highly sceptical of the value of lunar-eclipse omens for the dating of historical events (e.g. van Soldt 1994, Hunger 2000, 2002, Rochberg 2004: 270-1). Doubt arises from the general and repetitious nature of the apodotic phrases, the absence from them of named individuals such as kings, the invention of history that never was (as in $E A E \mathrm{XX} \S \mathrm{XI}$ when $\mathrm{Ur}$ is said to take over the hegemony of Babylon) and, finally, the total lack of such apodoses in Old Babylonian eclipse omens, a lack which implies that portent and prediction were paired many centuries after the time to which some of the apodoses are supposed to refer.

In addition it is well known that the redactors of Babylonian omen texts used schematic patterns in elaborating their texts. In the lunar-eclipse omens of $E A E$ patterns emerge in the association of the various features of an eclipse and the political regions of the Babylonian world, themselves idealized as four quadrants: Akkad (Babylonia), Elam, Amurru and Subartu with Gutium (Rochberg-Halton 1988: 51-5). A logical relationship between protasis and apodosis was thereby artificially induced, which allowed extrapolation of matching protases and apodoses without empirical base. As in other omens, impossible observations are included, not only in the positing of eclipses on days of the lunar month when eclipses cannot take place, but also in the inclusion of eclipses of impossibly long duration. In Babylonian omen texts theory predominated over empiricism, with the consequence that, as texts were expanded and adapted to schematic patterns, any embedded historical data were subject to distortion and alteration. As one scholar puts it, "if [the lunar-eclipse apodoses] were occasioned by historical events at all, the description of these events may nevertheless have been altered in ways that make it impossible to identify their historical basis" (Hunger 2000: 158). Another astrological omen text long used as the foundation stone of early second-millennium chronology, the Venus tablet of Ammișaduqa ( $E A E$ LXIII), is also now considered by some to present data too distorted to be a reliable chronological tool (Gasche et al. 1998: 72-4, Gurzadyan 2000: 180-3).

A further pitfall that attends work on the lunar-eclipse omens is the occasional unreliability of the edition that provides the primary data. A pertinent example for would-be chronologists is the portent of 14 Simanu predicting the death of a king of Ur, for it is often assumed to report an historical eclipse that attended the end of Sulgi (EAE XX §III). As edited by Rochberg, there were two versions of the protasis, which differed with regard to the details of the watches in which the eclipse occurred. One (A) read [EN.NUN A]N.ÚSAN ZI-ma [EN.NUN MUR]UB 4 .BA TAG- $u t$ and the other (B) had EN.NUN AN.ÚsAN im-šu-ul $\mathrm{k}\left[\mathrm{I}\right.$ ? . . .] (Rochberg-Halton 1988: 189-92). ${ }^{3}$ Commentators have reasonably assumed that these phrases, variously interpreted, represent key developments in the progress of the eclipse and have tried to take account of them in their reckonings of Ur III chronology (Koch 1998: 126, Gurzadyan 2000: 179, Huber 1999-2000: 60, 2000: 169 etc.). However valid their methods, the edition has misled them from the outset: the signs given as $i m-\check{s} u-u l \mathrm{KI}$ are actually it-ba-am-m[a] (MS U = BM 46239 obv. 9', coll.). The implication of the variants ZI-ma and $i t-b a-a m-m a$ for the reading of the text will be dealt with below, in the note on ll. 2-3. Rochberg's misreading is not an isolated error; others are corrected elsewhere in this article (see also George 1991).

Though the new source published here allows for a more complete reconstruction of the pseudohistorical apodoses, we have no desire to address chronological issues here. The historicity of the omens is not our present concern; instead we are interested in the recensional history of $E A E \mathrm{XX}$.

\footnotetext{
${ }^{3}$ The entire omen is quoted in three astrological reports (SAA VIII 4: 2-3, 300 rev. 6, 336 rev. 2), and in a NeoAssyrian excerpt tablet from Kuyunjik (Rochberg-Halton
} 
Rochberg identified two distinct recensions of this tablet of the series, one more copied in Assyrian script (Recension A) and another more commonly written in Babylonian script (Recension B). It will become quickly apparent that the Sippar manuscript does not consistently hold true to either, and is thus an eloquent witness to the instability of the textual tradition of $E A E$ in the various Babylonian scribal centres of the first millennium BC. The recensional complexity of the text current in the first-millennium scribal tradition is the subject of the commentary that follows our presentation of the new manuscript.

\section{Edition of IM 124485}

IM 124485 is described in its colophon simply as the "latter section" (Akk. pirsu ark $\hat{u}$ ) and accordingly gives the text only of the second half of the $E A E \mathrm{XX}$, covering months seven to twelve (\$§VII-XII in Rochberg's edition) and adding a section of summary (\$XIII). The tablet also bears the excavation number Sippar Library 19/2182, and is published by permission of the University of Baghdad and the Directorate-General of Antiquities in Iraq. Other tablets from the library are dated to the mid-sixth century and thereafter; IM 124485 was no doubt written at some date in this era, certainly before the library was abandoned in the early fifth century. The tablet measures $3.6 \times 9.2 \times 16.3 \mathrm{~cm}$. In the transliteration immediately below, signs marked with an asterisk are read from the photograph rather than the copy.

IM 124485. Copy and photographs: Figs. 1-4.

Text

$\S$ VII

1. [DIš ina $\left.{ }^{\mathrm{i}}\right]^{\mathrm{t}}$ tašrtîti $\left(\mathrm{du}_{6}\right)$ ud.14.kam attalâ(AN.MI) iškun(gar)-ma ilu(dingir) ina na'duri $\left(\operatorname{kan}_{5}\right)$-šu idi(á) im amurri(mar) eliš(an.ta) i"'adir $\left(\operatorname{kan}_{5}\right)^{*}-m a$

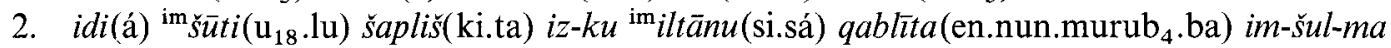

3. e-li ma-šá-lim itbâm(zi)-ma adi(en) namru(zálag) illik(gin) kakka[bu(mul) ina šurin]ni(šu.nir?) qaran(si) imitti(zag)-šú ithe(te)-ma

4. i*-gir-ma ina qaran(si) šumèli(gùb)-š́u izziz(gin) na'dur( $\mathrm{kan}_{5}$ )-šú tammar(igi)-ma

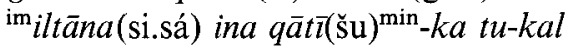

5. ina libbi(šà) ${ }^{\text {uru } m u-t a-b a l ~ p u r u s s u ̂(e s ̌ . b a r) ~ n a d i n(s u m) ~}{ }^{\text {uru } m u-t a-b a l ~ a-s ̌ a b-s ̌ a ́ * ~ q u r-r u-u b ~ d e n-l i ́ l ~}$

6. māta(kur) uk-tin ašăb(dúr)*-šá ina puhur (ukkin) ilī(dingir) ${ }^{\text {meš }}$ rabûti(gal) ${ }^{\text {meš }} i q$-ta-bi $m \bar{a} r$ (dumu) šarri(lugal) šá uru $m u$-ta-bal

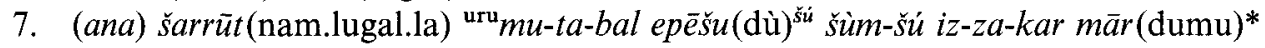
šarri( lugal) šá bár-sipa ${ }^{\mathbf{k i}}$

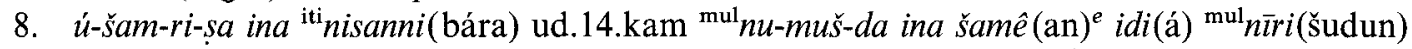

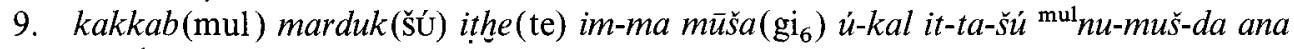
${ }^{\text {mul }}$ nìri(šudun)

10. $\check{\text { sa-pil ana }{ }^{\text {mul.d }} \text { marduk(amar.utu) } \check{s} a-q u \text { idi(á) šumēli(gùb) }{ }^{\mathrm{mul}} n u-m u s ̌-d a ~ h e-p i}$

11. mul.d marduk (amar.utu) kakkabu(mul) izziz(gub)-ma u namir(zálag) ašăb(dúr)* uru $m u$-ta-bal $q u r-r u-u b$ nandê(šub)* bābili(ká.dingir.ra) ${ }^{\mathbf{k i}}$

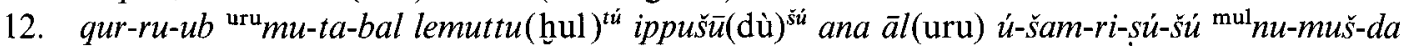

13. lemuttu (hul $)^{t \dot{u}} i$-rab ${ }^{\text {uru }}$ bar-si-pa še-ret-su bābilu(tin.tir) ${ }^{\mathbf{k i}} i$-pa-áššsar ahu(šeš) ana ahi(šeš)

14. ${ }^{\mathrm{f}}$ nukurta(kúr) išappar(kin) ina bi-ri-šú-nu dil-bat ${ }^{\mathrm{ki}}$ innaddi(šub) ${ }^{d i}$ uru $m u$-ta-bal innaddi(šub) ${ }^{d i}$

15. $\bar{a} l \bar{u}(\mathrm{uru})^{\mathrm{mešs}}$ inammirūu(zálag) ${ }^{\mathrm{meš}}$ na-mar $\bar{a} l \bar{\imath}(\mathrm{uru})^{\mathrm{meš}} q u r-r u-u b$ mār (dumu) šarri(lugal) šá bar$s i-p a^{\mathrm{ki}} \grave{s a}-q u$

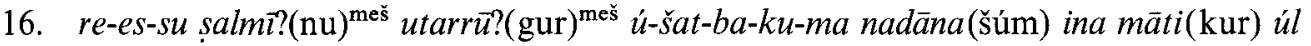

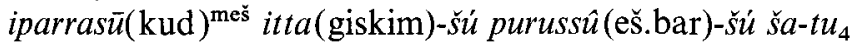

\section{$\S$ VIII}

17. DIš ina ${ }^{\mathrm{iti}}$ arahsamna(apin) ud.14.kam attalâ(AN.MI) iškun(gar)-ma ilu(dingir) ina

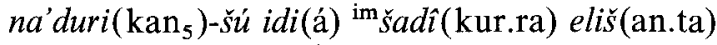

18. i"adir $\left(\operatorname{kan}_{5}\right)$-ma idi(á) ${ }^{\mathrm{im}}$ amurri(mar.dú) šapliš (ki.ta) $i z-k u{ }^{\mathrm{im} i l t a ̄ n u(s i . s a ́)}$

qablitta(en.nun.murub ${ }_{4}{ }^{*}$.ba) illik(gin)-ma! 
Obr.

5

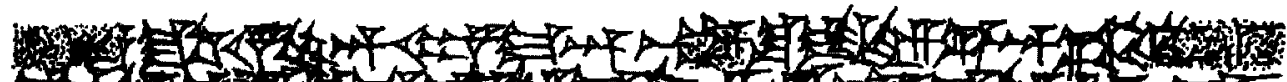
*5

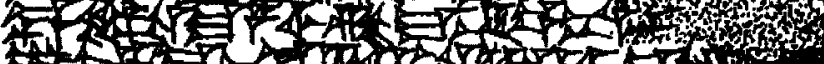

5

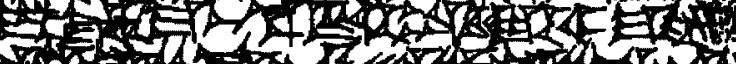

MC

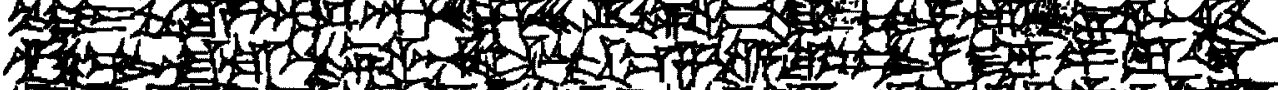

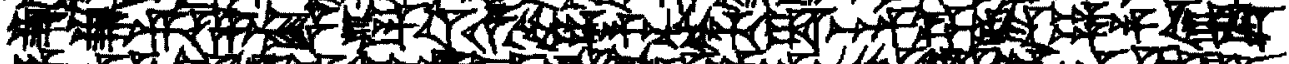

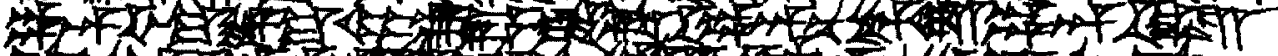

10

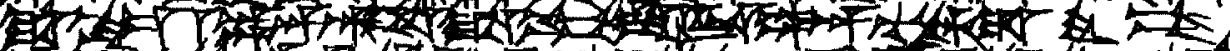

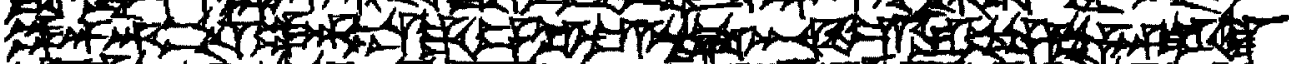

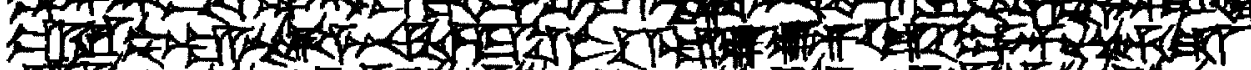

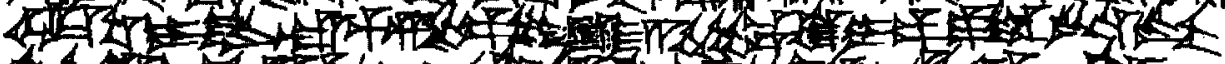

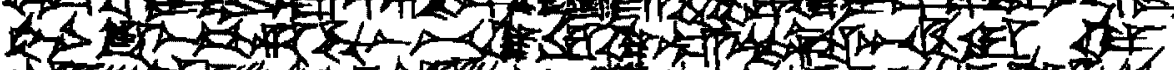

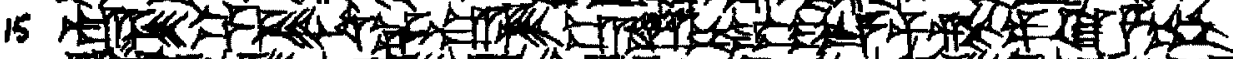

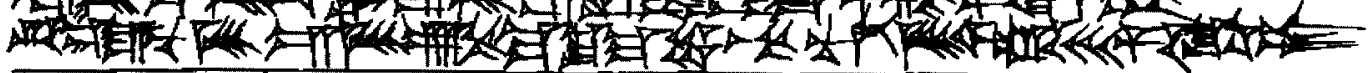

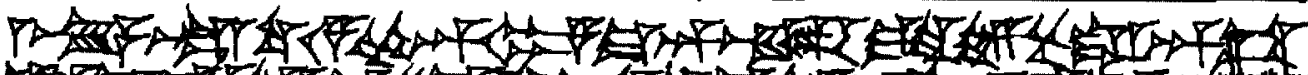

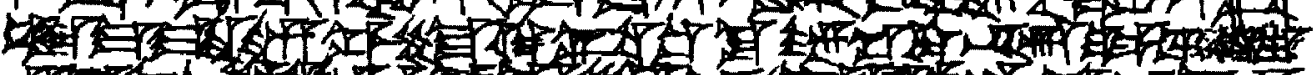

20

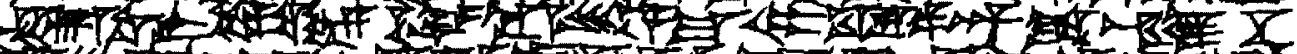

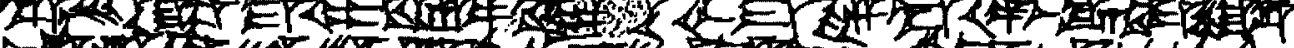

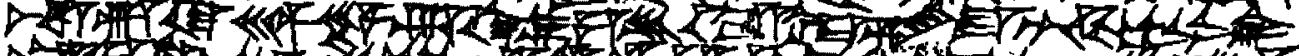

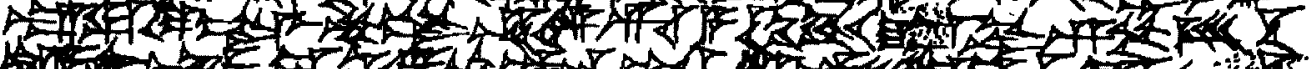

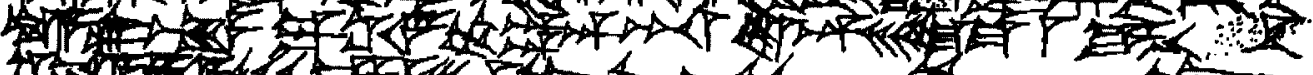
If

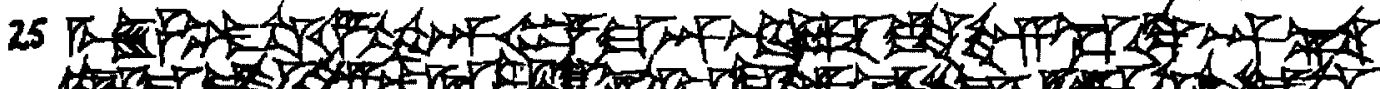

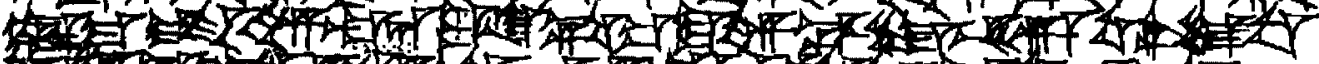

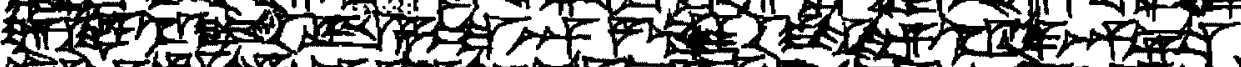

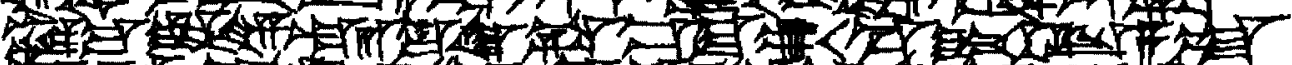

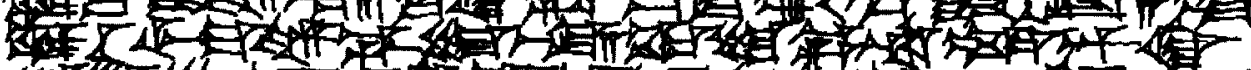

30 KA 3 (

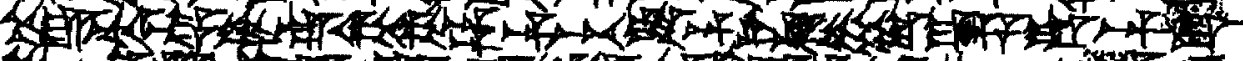

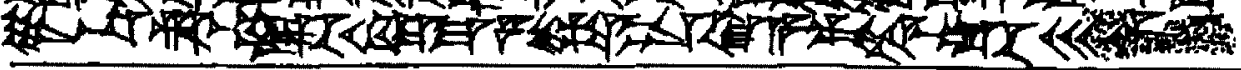

PSTF

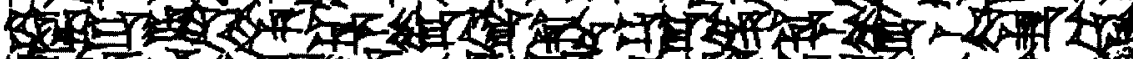

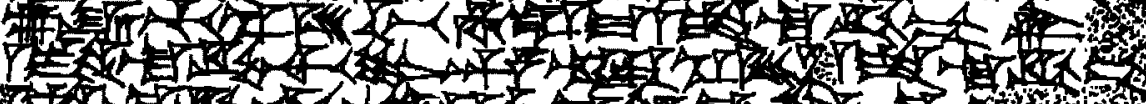

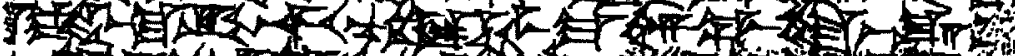

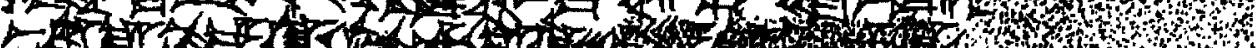

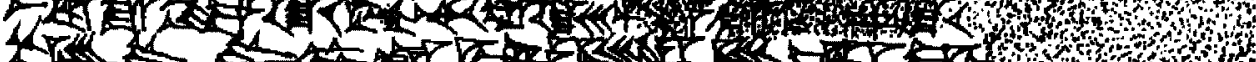

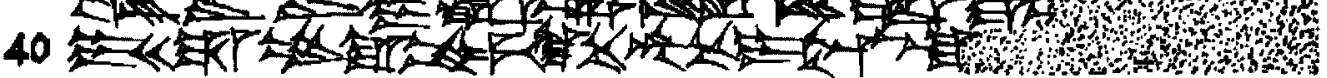

Fig. 1. IM 124485 obv., copy by F. N. H. Al-Rawi. 


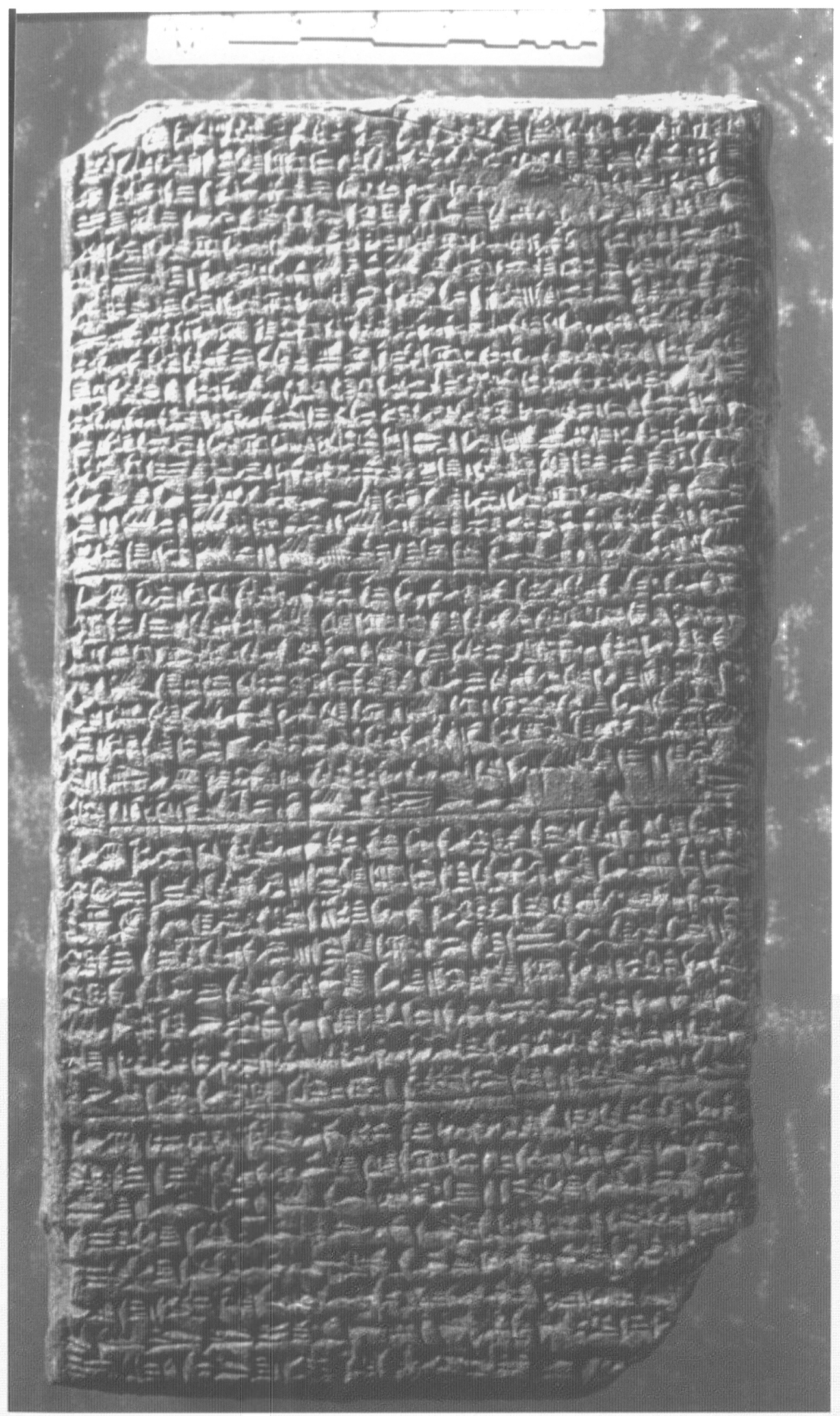

Fig. 2. IM 124485 obv. 
Rev.

F.

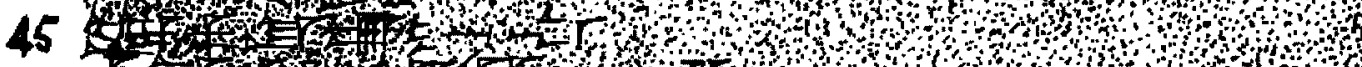

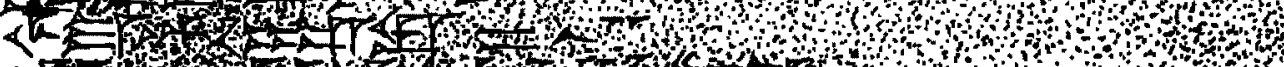

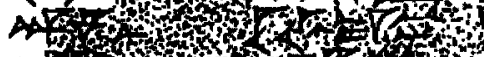

年,

50

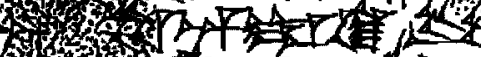

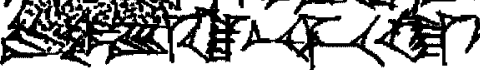

\section{5}

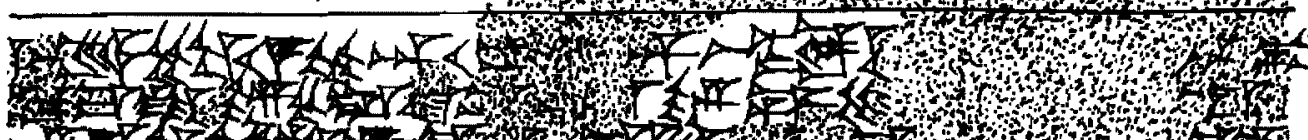
ing

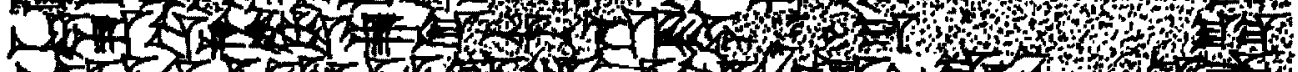

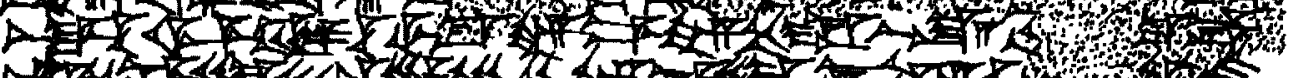
A

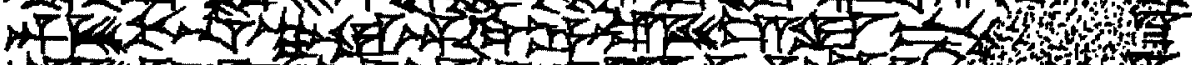
60 10 I 245 o 4. 35 , 7

65 36) 釉

Fig. 3. IM 124485 rev., copy by F. N. H. Al-Rawi. 


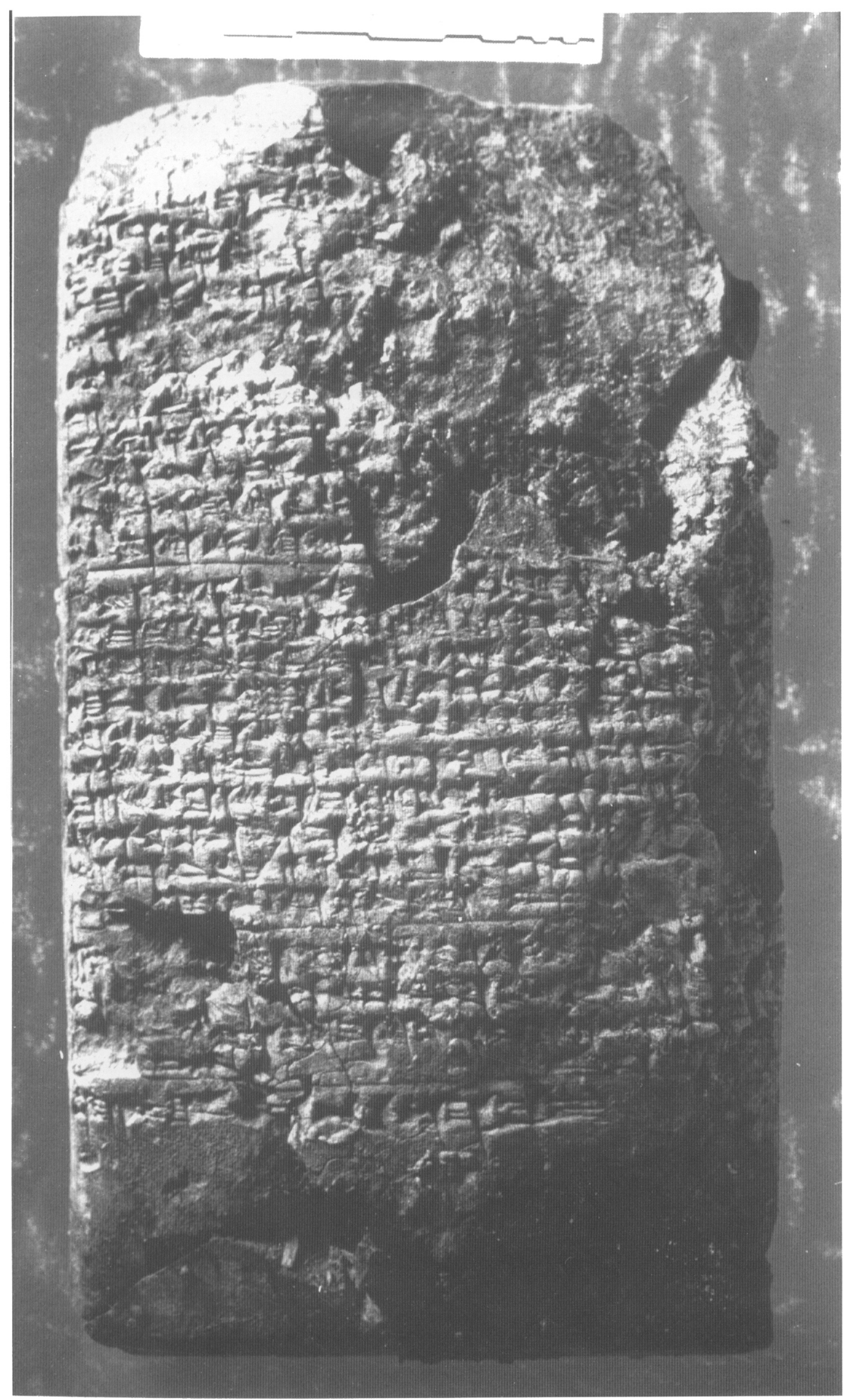

Fig. 4. IM 124485 rev. 


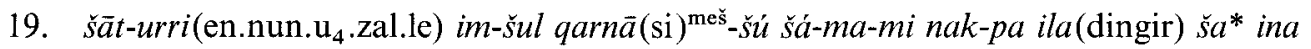
$n a^{\prime} d u r i\left(\operatorname{kan}_{5}\right)-\check{s ̆ u}^{\prime}$

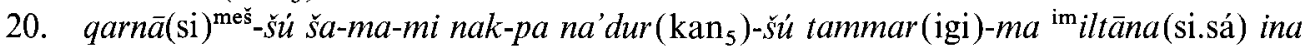
$q \bar{a} t \bar{t}(\check{\mathrm{s} u})^{\mathrm{min}}-k a \mathrm{tu}-k a l$

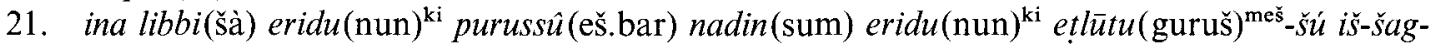
gi-šu palê( bala) šarri (lugal) inakkir (kúr) ${ }^{i r}$

22. ālu(uru) innaddi(šub) ${ }^{d i}$ šarru(lugal) ikkammu( lá) ${ }^{m u}$ šarru(lugal ) adi(en) kimti(im.ri.a)-šú

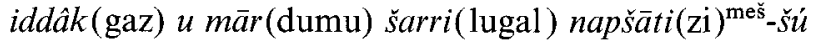

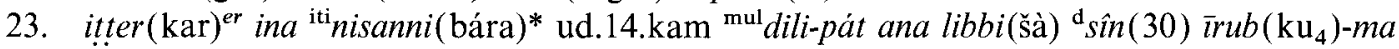
ana imitti(zag)-š́u

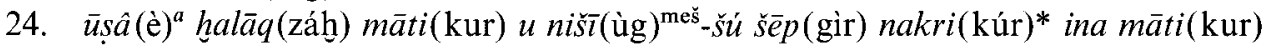
ipparras $(\mathrm{kud})^{a s}$

$\S \mathrm{IX}$

25. DIŠ ina ${ }^{\text {it }}$ kislimi (gan) ud.14.kam attalâ(AN.MI) iškun(gar)-ma ilu(dingir) ina na'duri( $\mathrm{kan}_{5}$ )-

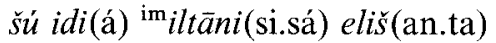

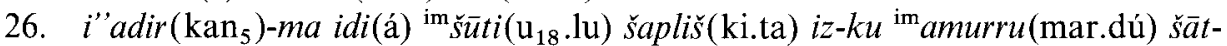
urri(en.nun.u $\left.\mathrm{u}_{4} \cdot \mathrm{zal} . \mathrm{le}\right)$

27. im-šul qaran(si) imitti(zag)-šú kap-șa-at ila(dingir) šá ina na'duri( $\left.\operatorname{kan}_{5}\right)$-šú idi(á)

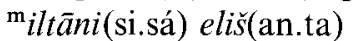

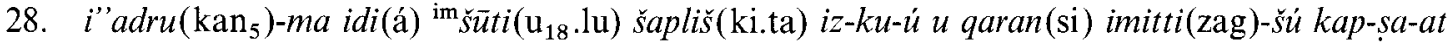

29. na'dur $\left(\mathrm{kan}_{5}\right)$-šú tammar(igi)-ma im amurra (mar.dú) ina qătī(šu ${ }^{\text {min }}-k a$ tu-kal ina libbi(šà) dêri (bàd.an) $)^{\mathbf{k i}}$

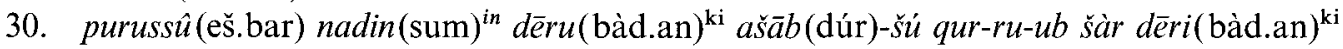
$\operatorname{imât}\left(\operatorname{ug}_{7}\right)-m a$

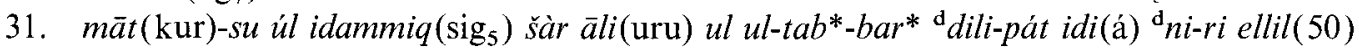
inappah(mú)-ma ina za-ra-an qablititi(murub 4 !)

32. in-na-țal ina na'duri $\left(\operatorname{kan}_{5}\right)$-šú eli ma-šá-li illik(gin) ki-a-am itta(gizkim)-šú u

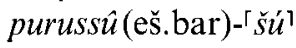

\section{$\S \mathrm{X}$}

33. DIš ina ${ }^{\text {iti }}$ tebêtti(ab) ud.14.kam attalâ(AN.MI) iškun(gar)-ma ilu(dingir) ina na'duri( $\left(\mathrm{kan}_{5}\right.$ )-šú idi(a) ${ }^{{ }^{i m} \breve{s} a d \hat{\imath}(k u r . r a) ~ e l i s ̌ s(a n . t a) ~}$

34. i"'adir $\left(\operatorname{kan}_{5}\right.$ )-ma idi(á) ${ }^{\mathrm{im}}$ amurri(mar.dú) šapliš(ki.ta) $i z-k u{ }^{\mathrm{im}}$ amurru(mar.dú) šăturri(en.nun.u. $\left.\mathbf{u}_{4} \cdot \mathrm{zal} .[\mathrm{le}]\right)$

35. ú -qát-ti qarnă(si) ${ }^{\text {meš }}$-šú mit-ḩa-ra-ma ištêt $(1)^{e t}$ la ik-bi-ir

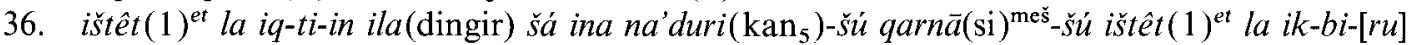

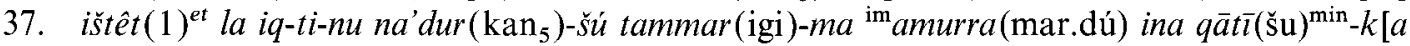
tu-kal]

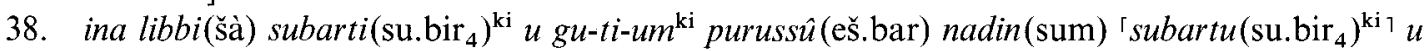
$\left[\mathrm{gu}-\mathrm{ti}-\mathrm{um} \mathrm{m}^{\mathrm{ki}}\right]$

39. ikkaššadū (kur) ${ }^{\text {meš }}$ amēlu(lú) amēla(lú) i-ra-sib nišūu(ùg $)^{\text {meš }}$ imaqqutā(šub $)^{\text {meš }}$ al-ma-n[a-tu]

40. i-min-da šàr subarti(su.bir $\left.{ }_{4}\right)^{\mathrm{ki}} m \bar{a} t a(\mathrm{kur}) i k a s ̌ s ̌ a d(\mathrm{kur})^{\dot{a} d} m a \bar{t} t a(\mathrm{kur}) i$-šal-lal ilu(dingir)* [šá eli $m a-\breve{s a ́}$-lim]

rev.

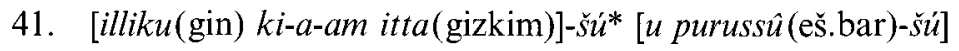

$\S \mathrm{XI}$

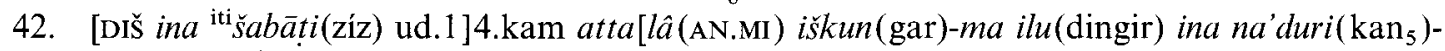
šú idi(á) $\left.{ }^{\mathrm{im}} \check{s} \bar{u} t i\left(\mathrm{u}_{18} \cdot \mathrm{lu}\right)\right]$

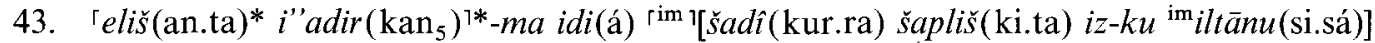

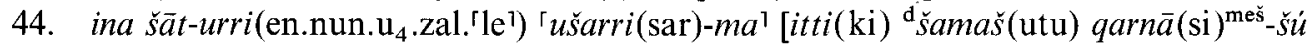
šamê(an $\left.)^{e}\right]$

45. nak*-pa šurinna(šu.nir) ${ }^{\ulcorner} k a^{\top}$-la*-[šú úl iktum(dul)-ma it-bal ina ud.28.kam] 
46. tammar(igi)-ma attahî (AN.MI) qur-ru-rub inappah(mú) ${ }^{1}-\left[m a ~ s a ̄ m\left(\mathrm{sa}_{5}\right)\right.$-ma attalâ (AN.MI) $\dot{u}-k a l-$ lam-ka]

47. ila(dingir) šá ina [na'duri $\left.\left(\mathrm{kan}_{5}\right)\right]$-šú innamru(igi)-ma itbalu(tùm) na'dur $\left(\mathrm{kan}_{5}\right)$-šúu tammar(igi)-ma ${ }^{1 \mathrm{im}}$ iltāna(si.sá) ina qāt $\left.\bar{\imath}(\mathrm{s} u)^{\mathrm{min}}-k a t u-k a l\right]$

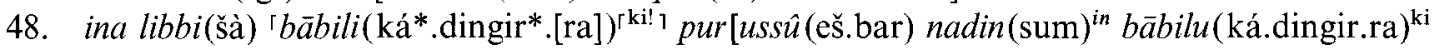
halāq(záh)-š́u

49. qur-ru-ub mātu(kur) sapihgtu(bir) ${ }^{\text {tum }}$ sap [āhn(bir)-šá qur-ru-ub den-lil māta(kur) ka-la-šá i-ru$u r]$

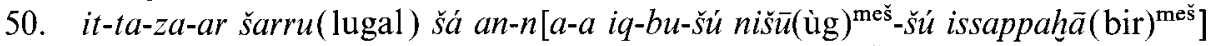

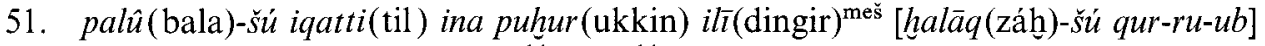

52. palê(bala) bābili(ká.dingir.ra) ${ }^{\mathrm{ki}}$ úri $\left[m^{\mathrm{ki}} i k k i m(\mathrm{kar}) k i \check{s} s \bar{u} t\left(\right.\right.$ šúu $^{u t}$ bābili(ká.dingir.ra) $\left.{ }^{\mathrm{ki}}\right]$

53. úrim $^{\mathrm{ki}}$ ileqqe(ti) $)^{q e ́ ~} i l u$ (dingir) [šá ina na'duri $\left(\mathrm{kan}_{5}\right)$-šú mūšu $\left(\mathrm{gi}_{6}\right)$ is-su-hu ki-a-am itta(gizkim)-š́u u purussîu(eš.bar)-š́u

\section{$\S$ XII}

54. DIš ina ${ }^{\mathrm{iti}}$ addari(še) ud.14.kam attalâ(AN.MI) [iškun(gar)-ma] ilu(dingir) ina na'duri $\left(\mathrm{kan}_{5}\right.$ )- šú [idi(á) ${ }^{\text {im } i l t a ̄ n i(s i . s a ́)] ~ e l i s ̌(a n . t a) ~}$

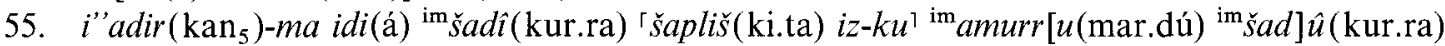

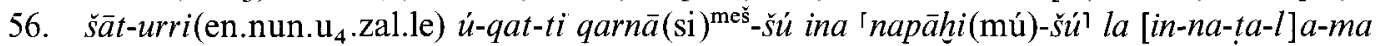

57. ina rabê(gal)-šú innattalä (igi) ${ }^{\mathrm{me}}$ na'dur $\left(\mathrm{kan}_{5}\right)$-šú tammar(igi)-ma ${ }^{\mathrm{im}}$ amurra(mar)

$\mathrm{im}_{\text {šada }}$ (kur.ra) ina qāt $\bar{l}(\check{\mathrm{s} u})^{\mathrm{min}}-k[a t] u-k a l$

58. ina libbi(šà) $m \bar{a} t$ (kur) amurri(mar.dú) purussû(eš.bar) nadin(sum) ${ }^{i n}$ āt (kur)

im amurri (mar.dú) ištu(ta) re-š [i-šá inn]ešši (sùḥ̆!)

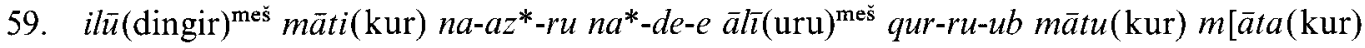
$i k k] a l\left(\mathrm{gu}_{7}\right)$

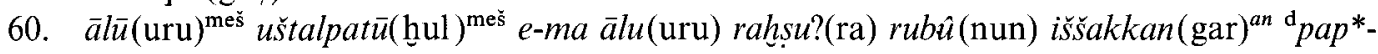
sukkal ippuh(kur)-[m]a

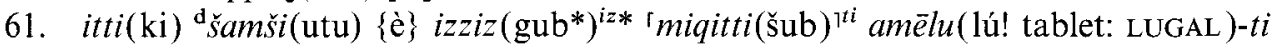
$b \bar{u} l\left[i\left(\text { máś}^{*} \text {.anše }\right) \times(\mathrm{x}) \mathrm{x}^{\mathrm{m}}\right]^{\mathrm{es}}$

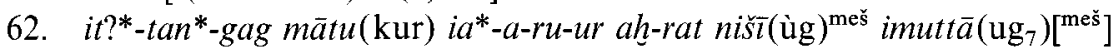

63. ilu(dingir) ina na'duri $\left(\mathrm{kan}_{5}\right) \check{s} a ̆ t-u r r i\left(\right.$ en.nun. $\mathrm{u}_{4}$.zal.le) $u$-gam*-m[ir]

\section{$\S$ XIII}

64. DIš att[alâ(AN.MI) ina(ta) $x]$ arhi(iti) ina(ta) ud.7.kam ud.14.kam ud.21.kam iškun(gar) šahluqtu (níg.ha.l[am].ma)

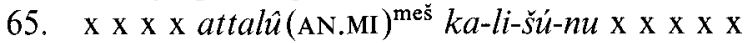

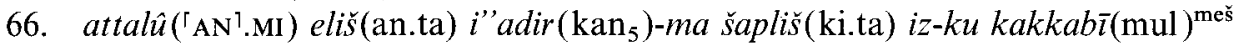
mașșarāti(en.nun $)^{\text {meš }}$

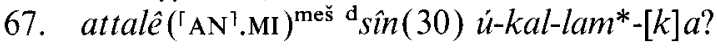

68. pir-su ár-ku-ú $\ulcorner k \bar{m} m a(\mathrm{gim})\urcorner$ labiri(sumun)-šú šatiir(sar)-ma ba-ár

\section{Translation}

\section{$\S$ VII}

${ }^{1}$ [ (If) on] 14th Tašritu (the moon god) brings about an eclipse and the god in his eclipse becomes dark on the side west above and ${ }^{2}$ clear on the side south below, a north wind (blows), in the middle watch he reaches halfway, ${ }^{3}$ he keeps going beyond halfway and continues until it becomes light, (and if) a star [in the "emblem"] approaches his right cusp, then "twists round and stands at his left cusp: you observe his eclipse and keep in mind the north wind. ${ }^{5}$ A prediction is given for Mutabal: the resettling of Mutabal is at hand, Enlil ${ }^{6}$ has stabilised the land; he has commanded its resettling in the assembly of the great gods. The crown prince of Mutabal ${ }^{7}$ will be called to exercise the kingship of Mutabal. He will afflict (! tablet: afflicted) the crown prince of Borsippa ${ }^{8}$ with misery. 
(If) on 14th Nisannu the star of Numušda in the sky beside the Yoke Star ${ }^{9}$ approaches the star of Marduk, retaining its portent by day and by night, (and if ) Numušda ${ }^{10}$ is lower than the Yoke Star and higher than the star of Marduk, (on) the left side (of) Numušda ... (scribal note: broken) ... ${ }^{11}$ the star of Marduk, a star is present and shining brightly: the resettling of Mutabal is at hand; the desertion of Babylon ${ }^{12}$ is at hand. Mutabal will behave wickedly; the city that afflicted it with misery the star of Numušda ${ }^{13}$ will pay back with misfortune. Babylon will deliver Borsippa from its punishment. Brother ${ }^{14}$ will declare war on brother: between them Dilbat will be abandoned, Mutabal will be abandoned. ${ }^{15}$ Cities will become "bright": the "brightening" of cities is at hand. The crown prince of Borsippa, exalted will be ${ }^{16}$ his head. Statues(?) will again(?) be dumped in a pile, commerce(?) will not cease in the land. Its portent and prediction are this(?).

\section{$\S$ VIII}

${ }^{17}$ (If) on 14th Arahsamna (the moon god) brings about an eclipse and in his eclipse the god ${ }^{18}$ becomes dark on the side east above and clear on the side west below, a north wind (blows), in the middle watch he sets out and ${ }^{19}$ in the dawn watch he reaches halfway, (and) his cusps are jabbing the sky: observe the eclipse of the god ${ }^{20}$ whose cusps in his eclipse were jabbing the sky, and keep in mind the north wind. ${ }^{21} \mathrm{~A}$ prediction is given for Eridu: the menfolk of Eridu will be slaughtered, the king's reign will be over, ${ }^{22}$ the city will be abandoned, the king will be captured, the king will be put to death along with his family, but the crown prince ${ }^{23}$ will escape with his life.

(If) on 14th Nisannu Venus enters the moon and ${ }^{24}$ comes out on its right side: destruction of the land and its people; enemy feet will be kept out of the land.

\section{$\S \mathrm{IX}$}

25 (If) on 14th Kislimu (the moon god) brings about an eclipse and in his eclipse the god ${ }^{26}$ becomes dark on the side north above and clear on the side south below, a west wind (blows), in the dawn watch ${ }^{27}$ he reaches halfway, (and) his right cusp is curled: observe the eclipse of the god who in his eclipse ${ }^{28}$ became dark on the side north above and clear on the side south below, and whose right cusp was curled, ${ }^{29}$ and keep in mind the west wind. ${ }^{30} \mathrm{~A}$ prediction is given for Dēr: the resettling of Dēr is at hand, the king of Dēr will die, and ${ }^{31}$ his land will not have good fortune. The king of the city will not live long. Venus will flare up brightly beside the Yoke of Enlil and ${ }^{32}$ will be seen in the middle "band". (The god) in his eclipse went on beyond halfway: thus his portent and prediction.

\section{$\S \mathrm{X}$}

${ }^{33}$ (If) on 14th Tebètu (the moon god) brings about an eclipse and in his eclipse the god ${ }^{34}$ becomes dark on the side east above and clear on the side west below, a west wind (blows), ${ }^{35}$ in the dawn watch he brings (the eclipse) to an end, (and) his cusps are of equal size - the one not growing too fat ${ }^{36}$ nor the other too thin - observe the eclipse of the god whose cusps in his eclipse, the one did not grow too fat ${ }^{37}$ nor the other too thin, and [keep] in mind the west wind. ${ }^{38} \mathrm{~A}$ prediction is given for Subartu and Gutium: Subartu and [Gutium] ${ }^{39}$ will be captured; man will smite man, people will perish, widows ${ }^{40}$ will proliferate; the king of Subartu will conquer the land, he will plunder the land. The god [who went ${ }^{41}$ on beyond halfway: thus] his [portent and prediction.]

\section{$\S X I$}

${ }^{42}$ [đ(If ) on] 14th [Šabạțu (the moon god) brings about an] eclipse [and in his eclipse the god] becomes dark [on the side south] ${ }^{43}$ above and [clear] on the side [east below, a north wind (blows),] ${ }^{44}$ in the dawn watch he begins (the eclipse) and [in the company of the sun his cusps] ${ }^{45}$ are jabbing into [the sky, he does not cover] the whole lunar disk (lit. "emblem") [and disappears] ${ }^{46}$ observe [on the 28th day], (to see if ) an eclipse is at hand: (the moon god) will rise, [be red and show you an eclipse] $-{ }^{47}$ observe the eclipse of the god who in his [eclipse] became visible and disappeared, and [keep in mind the north wind.] ${ }^{48} \mathrm{~A}$ prediction [is given] for Babylon: [the destruction of Babylon] ${ }^{49}$ is at hand; the scattered nation, [its] scattering [is near. Enlil cursed and] ${ }^{50}$ reviled [the entire land:] the king to whom [he said] "Yes", [his people will be scattered,] ${ }^{51}$ his reign will come to an end, in the assembly of the gods [his destruction is at hand.] 
${ }^{52} \mathrm{Ur}$ [will steal] the hegemony of Babylon; ${ }^{53} \mathrm{Ur}$ will take over [the power of Babylon.] The god [in whose eclipse the night elapsed: thus his portent and prediction.]

$\S X I I$

${ }^{54}$ (If) on 14th Addaru (the moon god) [brings about] an eclipse [and] in his eclipse the god becomes dark [on the side north] ${ }^{55}$ above and clear on the side east below, a west and an east wind (blow), ${ }^{56}$ in the dawn watch he brings (the eclipse) to an end, (and) his cusps cannot [be seen] ${ }^{57}$ when he rises but can be seen when he sets: observe his eclipse and keep in mind the west and east winds. ${ }^{58} \mathrm{~A}$ prediction is given for the land of Amurru: the land of Amurru, from its top (down), [will fall] into chaos; ${ }^{59}$ the gods of the land are accursed, the desertion of cities is at hand, nation [will] devour nation, ${ }^{60}$ cities will be sacked; wherever a city is flattened, a prince will be established. ${ }^{4}$

(If) Papsukkal rises and ${ }^{61}$ stands present with the sun, downfall of humans (! tablet: kingship) (and) wild animals, [cattle (or sheep)] will often (be heard) braying, ${ }^{62}$ the land will fall into panic, the posterity of the people will die. ${ }^{63}$ The god completed the dawn watch while eclipsed.

\section{§XIII}

${ }^{64}$ (If the moon god) brings about an eclipse [in the $x$ th] month on the seventh day, fourteenth day (or) twenty-first day: (it is a portent of) destruction. ${ }^{65} \ldots$ all eclipses . . ${ }^{66}$ (If) the eclipse becomes dark above and clear below: stars, watches, ${ }^{67}$ eclipses, the moon will show (them) to you.

${ }^{68}$ Latter section, written and checked according to its original.

\section{Notes}

1. The spelling ${ }^{\text {im }}$ MAR for amurru is a common abbreviation also used in 1.57 of this tablet.

2. Here and in all the following lunar-eclipse omens, the name of the wind is an abbreviation for ina lumun libbīšu iltānu etc. itbēma "during his evil portent (i.e. the moon's eclipse) a north etc. wind arises" (as in $E A E$ XX §I; see Rochberg-Halton 1988: 184).

2-3. The clauses in $E A E \mathrm{XX}$ mentioning the three watches of the night contain technical terminology that has caused some difficulty in the past, especially the verbs mašalu and ZI, which both occur here. Noting the

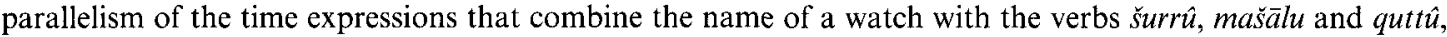
Rochberg understood the watch to be adverbial and identified the grammatical subject of ušarri, imšul and uqatti as ilu "the god", i.e. the moon in eclipse (Rochberg-Halton 1988: 45), so that, for example, in EAE $\mathrm{XX} \S \mathrm{V}$ qablitta imšul is translated "in the middle watch [the moon] is half (eclipsed)" (Rochberg-Halton 1988: 196).

In support of Rochberg's position we note that sometimes scribes placed the preposition ina before the watch name, clearly marking it as adverbial ( $E A E$ XX §I.2 MS D 15, ed. Rochberg-Halton 1988: 185; §VII MS D rev. 5, ed. ibid. 203; $\S$ XI 1.44 of the present tablet). Without ina the watch names can be read in the accusative, as we have done, following the example of an Old Babylonian lunar protasis, BE $i$-lum ba-ra-artam $i$-na UD.9.KAM $a r-h i-i s ̌$ i-te-ru-ub "if in the evening watch on the ninth day the (moon) god goes in too early" (Bauer 1936: 310 11. 15-16). On the other hand, several tablets of $E A E$ preface the watch name with a preposition much more consistently, and this seems to be normal usage, for outside certain tablets of $E A E$ adverbial use of the watch names without any preposition is very rare. Accordingly, it may be that the formulation EN.NUN $x$ meaning "in watch $x$ " is another example of abbreviated writing in $E A E \mathrm{XX}$ and stands for ina EN.NUN $x$.

There is a more general point in favour of Rochberg's position. Lunar eclipses were the work of the moon god and, in descriptions of an eclipse's progress, Sîn is clearly the unspoken subject of many of the various verbs that are employed: with attal $\hat{u}$ "eclipse" as the explicit or implicit object, the moon god "brings the eclipse about" (attalâ iškun), "makes it begin" (ušarri, factitive contra $C A D \breve{\mathrm{S}} / 3$ 359), and "brings it to an end" (uqatti). The phrasing fits the Babylonians' anthropomorphic conceptualizing of lunar eclipses and other celestial phenomena, on which see Rochberg 2004: 72. It makes for a coherent approach if the agency of Sîn is also observed in other verbs that describe the eclipse's progress: thus the moon god "becomes seen" (innamir), "goes" (illik), "arises" (itbâ), "reaches half" (imšul) and "removes" (itbal) his face. More idiomatic translations of some of these verbs will be offered as they occur.

The identification of the moon god as the logical subject of verbs that describe the eclipse's progress makes it necessary to reject the ad hoc translations of mašalu and ZI in the protasis of EAE XX §III proposed by the physicist Peter Huber (1999-2000: 60, 2000: 169), for whom the eclipse was the subject and the watch the object, and by Johannes Koch (1998: 126 "die Abendwache vorübergeht", "halb vorüber ist") and V. G. Gurzadyan (2000: 179: "the evening watches passes", "is half over"), for whom the subjects were the 
watches; as we have noted in the introduction, imšul is in any case a phantom in that protasis, deriving from a misreading.

As for zI, Rochberg read this as a logogram for nasāhu and took this to mean "to pass" a watch, so that, for example, she renders barärïta issuhma in EAE XX §III as "(the eclipse) passes the first watch" (RochbergHalton 1988: 189). The problem with this is that nasahu does not mean to spend time; the verb for that is šutabrû. As a technical term in measuring time, nasāhu can mean "to go by, elapse" of days and other units of time, a usage too common to need more than a reference to the dictionaries $(C A D \mathrm{~N} / 2: 10-11$ plus 1.53 of this tablet and its duplicates). Some have read barārìtu issuh(zi)-ma in EAE XX \$III and translated accordingly (Koch 1978: 126, Gurzadyan 2000: 179, quoted above). But all this is no longer relevant, for, as noted in the introduction, one witness (MS U) of EAE XX §III barārita ZI-ma qablìta ilput writes the first verb as $i t-b a-a m-m a$. The correct reading of ZI-ma in the watch clauses of lunar-eclipse omens is therefore not issuh-ma but itbâm-ma, and thus we have read it here. The verb also occurs spelled phonetically in $E A E$ XX §II, where the sense is clear despite the broken context (MS S 28-9, coll.): barārita(en.nun.an.usan) [...

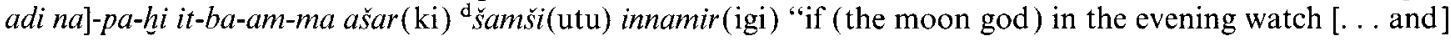
he keeps going [until] dawn and is visible alongside the sun". In $E A E \mathrm{XX}$ \&III the subject of both verbs in the passage barārita itbâmma qablitta ilput is the moon god: "(if) he keeps going through the evening watch and then touches the middle watch". These instances also determine that the verb tebu, when used of the moon, does not mean "to rise" (which is asû, napāhu) but "to make progress".

Returning to the passage under comment: if the moon god was already half-eclipsed in the middle watch and remained visible at dawn, §VII as it now stands reports an impossibly long eclipse. In a text which is deeply schematic physical impossibility is not a fatal objection, and over-long eclipses have been noted in other protases of $E A E$. It was perhaps for this reason, however, that ancient commentators came up with an alternative understanding of qablita imšul. In explaining what is meant by this expression in $E A E \mathrm{XX}$ $\$ 1 \mathrm{~b}$, the recently published Late Babylonian commentary from Uruk has this to say:

qablīta(en.nun.murub.ba ${ }_{4}$ ) im-šil-ma a-di namru(zálag) illik(gin) đšamaš(utu) là ìmur(igi)-šủ: ina mi-šil

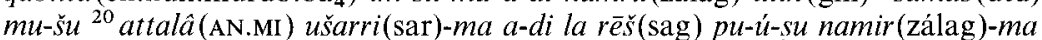

Uruk IV 162 obv. 19-20, coll. Reynolds

"(If) in the middle watch (the moon god) reaches halfway and continues (in eclipse) until it is light (but) the sun does not see him": (this means the moon) began the eclipse at midnight and stayed shining right up to (the emergence) of the first tip of the white part (of the sun's disk).

The protasis under comment describes an overlong eclipse of much the same duration as that in EAE XX §II. The explanation appended to it glosses qablitta imšul "in the middle watch he reached halfway" with a temporal phrase, ina mišil müši "at midnight", demonstrating clearly that the expression qablīta imšul has been reinterpreted as qablītu imšul "the middle watch was half over". While qablītu imšul is perfectly good Akkadian and elsewhere might signify midnight, we do not think this passage of commentary is a vindication of the translations of Koch and Gurzadyan in the present context. Rather it is an example of the inventiveness of late scholars working in a tradition where the ascription of alternative and supplementary meanings to written portents was part of the philological method; for other, unambiguous examples of the reinterpretation of phrases of protasis on the same tablet see below, the commentary on \$XII Scholia.

The last matter for comment in this passage is the meaning of eli mašăli in 1. 3. This expression also occurs in the summaries of $\S \mathrm{IX}$ and X (1l. 32 and 40 of this manuscript), where the verb tebu is replaced by alāku and no watch is at issue. Rochberg comments that "whether mašălu refers to the midpoint of the eclipse duration or of the duration of the night is not known" (Rochberg-Halton 1988: 201). It seems a little superfluous, in a protasis that records an eclipse's progress from the middle watch to dawn, to state explicitly that the eclipse carried on after midnight. More probably the expression eli mašăli alāku/tebû signifies passage beyond the mid-point in a total or near-total eclipse, i.e. when the lunar disk is more than half covered by the earth's shadow. A comparable usage of mašalu occurs in the line of the Babylonian poem of creation in which Marduk determines when the moon should be at first quarter (Enüma eliš V 17): ina UD.7.KAM a-ga-

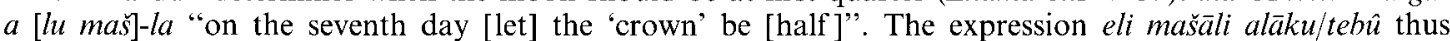
describes a continuing decrease in the size of the lit surface of the moon after half of it has already been obscured (imšul). It is when this stage of an eclipse is reached that the lit surface most resembles a crescent, and so we note that what the many protases of $E A E \mathrm{XX}$ find especially portentous is the particular shape or other attribute of the moon god's horns: these are the crescent's cusps (11. 3-4, 20, 27, 35-6, 44-5, 56-7 of the present manuscript).

3. The lacuna is restored from BM 38164 (Rochberg-Halton 1988: 220, Text a) iil 3': MUL ina ŠU.NIR SI ZAG-šú TE- $m[a \ldots]$ (coll.).

4. The significance of the wind's direction for the prediction is now explicitly stated in the Late Babylonian commentary on EAE XX, in the section on $\S 1$ (Uruk IV 162 obv. 7-9, coll. Reynolds): šăru(im) šá ${ }^{8}$ ina $q \vec{a} t \bar{l}(\breve{\mathrm{s} u})^{\mathrm{min}}-k a$ tu-kal : šăru(im) šá ana mätäti(kur.kur) il-la-ku pi-šir a-na libbi(šà) ${ }^{9}$ ta-qab-bi "the wind that you keep in mind (means) the wind that blows on the lands; thereby you pronounce the prediction".

10. The missing text cannot yet be recovered, for other witnesses to this passage are damaged: see the commentary below on the supplementary omen of $E A E \mathrm{XX} \$ \mathrm{VII}$.

15. The "brightening" of the cities may refer to festivities, for namāru is used to describe the mood of such 
occasions; however, this hardly fits the gloomy fortunes predicted for Babylon, Dilbat and Mutabal in the immediately preceding lines.

16. The decipherment of the last two clauses of the apodosis is provisional. As read here, the reference seems to be a scenario in which statues were stripped of their costly metals and precious gems and cast aside; revenue so obtained bolstered the purchasing power of the great institutions in times of insolvency. The final word of the clause of summary, if correctly read $s \bar{a} t u$, is a solecism; the clause is assumed to be an inferior alternative to $k \vec{l}$ am ittašu u purussîusu, which rounds off other sections of EAE XX (see 1l. 2, 41, 53 of this tablet).

31. The phrase zarān qabliti is explained as the well-known harrān šüt Ellil "Path of the Enlil-Stars" by the Late Babylonian commentary from Uruk (Uruk IV 162 rev. 4'-5'), quoted in the commentary below under §IX Scholia.

32. The summarizing clause is often couched as a relative clause, as in MS M at this point (CTN IV 5 iv 20-1): ilu(dingir) śá eli(ugu) ma-šá-li $[i l l i k u \text { (gin) }]^{k u}\left[{ }^{21} k i\right]$-a-am itta(gizkim)-šú purussû(eš.bar)-š́u; see similarly 11. 40-1, 53 of this tablet. In omitting ilu ša the present text follows the example of Rochberg's MS f (quoted below in the commentary on §IX Apodosis and summary).

34-5. The verb of the temporal clause, uqatti, is transitive, the object being the eclipse (attalâ) not the name of the watch (contra Rochberg-Halton 1988: 46). Compare, as one among several similar instances, the protasis of $E A E \mathrm{XXI} \S \mathrm{V}$ : ina šăt-urri(en.nun.u 4 .zal.le) $u$ šarri(sar)-ma ú-qat-ti-ma $i z$ - $k u$ "in the dawn watch (the moon) begins and ends (an eclipse) and becomes clear". To see out a watch is expressed instead with ugammir (as in 1.63 of the present tablet) and igmur.

40-1. The restoration of the end of the apodosis follows Rochberg's MS Q (Rochberg-Halton 1988: 210), the only source for $\S \mathrm{X}$ that has an apodosis identical to that of the Sippar tablet, and MS M (CTN IV 5), which has the same protasis.

42-53. This section is restored from MSS Q and M.

45,47 . It is nothing new to note that the verb itbal conveys disappearance in the context of astronomical observation. The usage is idiomatic, with ellipsis of an accusative noun signifying the god's celestial manifestation: Sîn anthropomorphically "takes away" his lunar self.

46. Observation of the moon on the 28th day, i.e. the month's last visible moonrise just before dawn, was a Babylonian technique for predicting eclipses in the short term (see Rochberg 2004: 272).

56. For šât-urri uqatti see above, on 11. 34-5.

56-7. The tense of innattala follows MS Q iv 20': in-na-ta-la-ma.

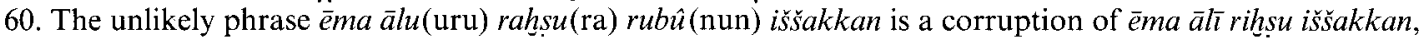
which occurs correctly in MSS Q iv 25', b rev. 11', Y rev. 13' and the commentary MS j rev. $9^{\prime}$ (see below on $\S \mathrm{XII})$; the corruption arose probably through a misreading of RA-șu $(=$ rihșu) as RA NIN, with NIN $(=b \bar{e} l t u$ "mistress") subsequently corrected to NUN (= rubu "prince").

61. The emendation from šarrüti "kingship" to amēlüti "mankind" is made in the light of other versions of this omen: see further the commentary below on §XII Supplementary omen and summary.

62. The word read it-tan-gag is provisionally taken as ittanaggag from nagāgu "to bray, neigh", but without collation and in the absence of well-preserved parallels the decipherment of the first sign is not secure; other derivations are possible. The apparent lack of agreement between the singular predicate and the lost subject (1. 61: [x (x) x.M]EŠ, with its plural determinative, might be resolved by positing a collective such as sugullu "cattle" or sēnu "sheep and goats".

64. The beginning of the line is restored after the pattern of $E A E \mathrm{XXII}$, where the monthly sections begin DIŠ TA 1 (2, 3 etc.) ITI TA UD.14.KAM " $ๆ$ (If an eclipse occurs) in the first (second, third etc.) month on the fourteenth day". As a writing of ina, TA is common on that tablet.

67. The reading ukallamka recommends itself in the light of $1.46 / / \mathrm{M}$ iv $27 / / \mathrm{Q}$ iv $10^{\prime}$.

\section{Commentary}

The purpose of this commentary is to set out the text of EAE XX $\S$ VII-XIV in a way in which the different scribal traditions can be more easily distinguished than is possible in the existing edition, at the same time correcting the errors of transliteration perpetrated therein. All tablets in the British Museum, London, and most of those in the Vorderasiatisches Museum, Berlin, have been collated against the original cuneiform by the good grace of the museum authorities. In Baghdad, it was not possible to collate IM 124485. The commentary tablet IM 75990 (Uruk IV 162) was collated on our behalf by Frances Reynolds. The relevant part of the Nimrud exemplar, MS M (CTN IV 5), was read against the published photograph (Wiseman and Black 1996: Pl. 145). This work achieved considerable gains, and the results inform all the transliterations given in what follows. Ideally, the whole tablet needs to be re-edited and cuneiform copies made of those many manuscripts for which none is available, but that task must await some other scholar who can devote to it the necessary time and energy. 


\section{Manuscripts}

Autopsy of the tablets provoked the following comments on Rochberg's list of manuscripts of EAE XX (Rochberg-Halton 1988: 174-5).

$\mathrm{N}=\mathrm{Sm} 459$ : This manuscript is very similar physically to K 12109 (Fragment 3 in RochbergHalton 1988: 228); Sm 237 (Fragment 5, pp. 228-9) might also belong to the same tablet.

$\mathrm{P}=$ VAT 11787 and $\mathrm{Q}=$ VAT $9419+11310$ : These fragments are parts of the same tablet.

$\mathrm{S}=$ "K $3561(+)$ 6141": The museum number is more accurately $\mathrm{K} 3561+8025+9502(+)$

$\mathrm{K} 6141+6148+6156+9108$. The two assemblages touch but do not join satisfactorily enough to permit gluing. According to its colophon this tablet is a copy made from a writing board dated to the eleventh year of Adad-apla-iddina, which gives a terminus post quem for the clay tablet (1058 $\mathrm{BC}$ in the conventional chronology). This ancestry lends the manuscript a certain authority, for Adad-apla-iddina's reign was the floruit of an important master-scholar, Esangil-kīn-apli of Borsippa, whom later tradition held responsible for establishing the text of Enüma Anu Ellil (see further below). The tablet displays a distinctive Babylonian ductus that falls somewhere between Middle Babylonian and Neo-Babylonian (diagnostic are the signs KI and DI with only one oblique wedge and RU with three separate vertical wedges), and uses old-fashioned spellings (e.g. šá-qú-ú, dam-qá-tum, ni-pí-ih) more frequently than other manuscripts of $E A E \mathrm{XX}$. Clearly it harks back to older conventions; we shall refer to it as an early Neo-Babylonian manuscript. Though the tablet was found in Nineveh it is unlikely to have been written there.

$\mathrm{Z}=$ VAT $9740+11670$ : This is a Neo-Assyrian tablet, not a Middle Assyrian one. Rochberg's Text $\mathrm{c}=$ VAT 9881 is probably part of the same tablet.

\section{Month VII. Tašrītu}

$\S$ VII Protasis. MS IM 1-4. The protasis of this omen in the Sippar manuscript (henceforth MS IM) agrees in essence with what is preserved of Recension A in Rochberg's edition (RochbergHalton 1988: 202-3), but not with that of her Recension B, which includes, where MS IM has simply na'duršu tammar, a wholesale repetition of the omen in what may be called a procedural clause (MS S rev. 3): ila ša ina na'durǐš idi amurri eli[š i' adrüma etc., etc. na'duršu tammar]. As the sources of this protasis now stand, it can be observed that Neo-Babylonian MS L (Kuyunjik) and Late Babylonian MSS IM (Sippar) appear to report one version of the text, while the older MS S (early NB) has another. Neo-Assyrian MS M (Nimrud) and Neo-Babylonian MS U (presumed to be from Babylon) could belong to either; but MS U can be associated with MS S on the evidence of earlier sections of the tablet. Neo-Assyrian MS D (Kuyunjik) deviates from both in at least one detail (see the collation at the end of this section). The Neo-Babylonian compilation tablet BM 38164 (also presumed to be from Babylon), a fragmentary source that Rochberg presented as an appendix to her edition of EAE XX (Rochberg-Halton 1988: 219-20, Text a), seems to follow MSS L and IM. There is no need to repeat here Rochberg's transliteration of the protasis of MS S, which is accurate except for a single misreading. But since the protasis of MS IM is translated above, we give now the translation of this variant:

${ }^{1}$ (If ) on 14th Tašritu (the moon god) brings about an eclipse and the god in his eclipse becomes dark on the side west above and [clear on the side south below, ${ }^{2}$ the north wind (blows), in the middle watch [he keeps going] beyond ${ }^{5}$ [halfway and ...: you observe the eclipse of $]^{3}$ the god who in his eclipse [became dark] on the side west above [and clear on the side south below, and keep in mind the north wind].

EAE XX §VII protasis MS S rev. 1-3

$\S$ VII Apodosis. MS IM 5-8. The sources agree that this eclipse omen concerns Mutabal. The apodosis of MS IM differs completely from what remains of the short apodosis handed down by Rochberg's Recension A (Neo-Assyrian MS D rev. 8'): šarru ana šarri nukurta išappar "king will declare war on king". It is more akin to her Recension B, but somewhat longer. Rochberg's

\footnotetext{
${ }^{5}$ Reading qablitta eli [mašăli itbâmma ... ]: see the collation of MS S rev. 2 at the end of this section.
} 
transliteration of the apodosis of Recension B, known only from early Neo-Babylonian MS S, is defective. A collated transliteration is given here:

${ }^{4}$ ina Š̀̀ ana URU.mu-ta-bal EŠ.BAR SUM-in U[RU.mu-ta-bal $a$-šab-šá qur-ru-ub den-lil KUR uk-tin]

${ }^{5} a^{1}$-šab-šá ina $p u$-hurur DINGIR.MEŠ GAL.MEŠ $i[q-t a-b i \ldots] \times$ x[ $\left.\ldots\right]$

EAE XX $\S$ VII apodosis MS S rev. 4-5

${ }^{4}$ Therein a prediction is given for Mutabal: [the resettling of Mutabal is at hand, Enlil has stabilised the land; ${ }^{5}$ he has commanded] its resettling in the assembly of the great gods [. . . ]

In addition, a third version of the apodosis occurs on the Neo-Babylonian compilation tablet MS a. The text of this apodosis, collated, is closer to MS S and MS IM than to MS D, but does not exactly match either. It runs as follows:

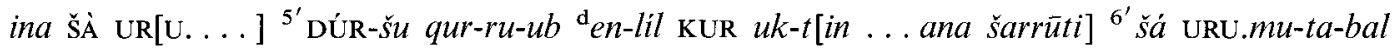
DÙ-š́u DUMU LUGAL $[\ldots]$

EAE XX $\S \mathrm{VII}$ apodosis MS a rev. iii $4^{\prime}-6^{\prime}$

[A prediction is given] for [Mutabal ... ${ }^{5}$ the resettling of Mutabal is at hand, Enlil has stabilised the land [ ...to $]^{6^{\prime}}$ exercise [the kingship] of Mutabal, the crown prince $[\ldots]$

§VII Supplementary omen and summary. MS IM 8-16. The apodosis of the eclipse omen is followed in other manuscripts, as in MS IM, by a supplementary omen concerning the stars of Numušda and Marduk. The reason for its presence may be that, like the preceding lunar-eclipse omen, it holds an apodosis concerned with the fortunes of Mutabal. Here, again, there is much variation. The early Neo-Babylonian source MS S reads as follows:

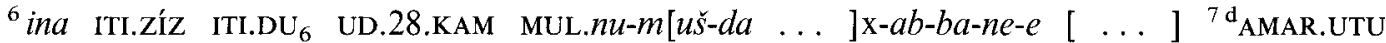

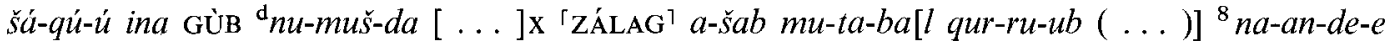

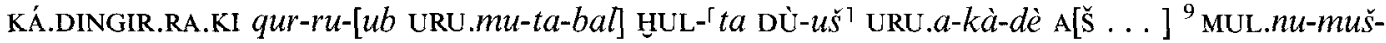

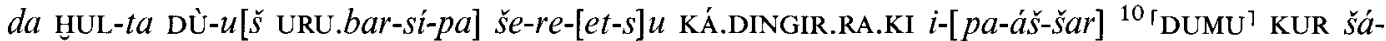
$n i$-tim-ma Aš.TE ${ }^{\top} \mathrm{DAB}-b a t^{\top}[\ldots]$ URU.bár-sipa $a$-šab-šá qur-ru-ub URU.DIDLI ZÁ[LAG.MEŠ] ${ }^{11^{1}} n a-$ mar ${ }^{1}$ URU.DIDLI qur-ru-ub [ . . ] URU.MEŠ [x x]

$E A E \mathrm{XX} \S \mathrm{VII}$ supplementary omen MS S rev. 6-11

${ }^{6}$ (If) on 28th Šabāṭu or Tašritu the star of Numušda [ . . ] . . [ . . (and if) Numušda is lower than the Yoke Star and $]^{7}$ higher than Marduk, on the left of Numušda [ . . a star is present and] shining brightly: the resettling of Mutabal [is at hand $(\ldots) ;]^{8}$ the desertion of Babylon is at hand. [Mutabal] will behave wickedly; the city Akkade [ ... ] ${ }^{9}$ the star of Numušda will treat to misfortune. Babylon will [deliver Borsippa] from its punishment. ${ }^{10}$ A native of another land will seize the throne. [ . . ] The resettling of Borsippa is at hand. Cities will become ["bright":] ${ }^{11}$ the "brightening" of cities is at hand. [ . . ] cities [ ... ]

Neo-Babylonian MS a has instead this text:

[ina MN $]^{6^{\prime}}$ UD. 14.KAM MUL.nu-muš-da ina AN- ${ }^{\top} e^{7}[\ldots]^{7^{\prime}} \dot{u}-k a l$ it-ta-šú MUL.nu-muš-da [ . . ]

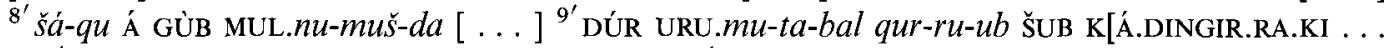

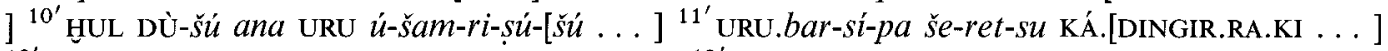
${ }^{12}{ }^{\prime}$ URU. $m u\left(!\right.$ tablet: BAL )-ta-bal ŠUB- $d i^{1}[\ldots]{ }^{13^{\prime}}$ qur-ru-ub ina IGI IRI.ME $\dot{u}$-[ . . . ]

EAE XX §VII supplementary omen MS a rev. iii $5^{\prime}-13^{\prime}$

$6^{\prime}$ (If ) on 14th [Nisannu(?)] the star of Numušda in the sky [beside the Yoke Star approaches the star of Marduk, ${ }^{7}$ retaining its portent [by day and by night,] (and if) Numušda [is lower than the Yoke Star and] ${ }^{8}$ higher than [the star of Marduk, (on) the left side of Numušda [. . a star is present and shining brightly: ${ }^{9}{ }^{\prime}$ the resettling of Mutabal is at hand, the desertion of Babylon [is at hand. Mutabal] ${ }^{10^{\prime}}$ will behave wickedly; to the city that afflicted it with misery [Numušda will bring misfortune.] ${ }^{11^{\prime}}$ Babylon [will deliver] Borsippa from its punishment. $[\ldots]^{12^{\prime}}$ Mutabal will be abandoned. $[\ldots]^{13^{\prime}}$ is at hand. Before the cities $[\ldots]$ 
The connection between protasis and apodosis is symbolic and a good example of the associations made in the development of Babylonian omen traditions. Numušda was the patron deity of Kazallu, a town in north Babylonia that evidence from Mari shows to have lain in the territory of the tribal clan Mutiabal. Town and tribespeople formed a military alliance, for example in the late nineteenth century when Kazallu and Mutiabal jointly occupied Larsa, before being driven out by Kudurmabuk early in the reign of his son, Warad-Sîn (Charpin 2004: 118). It is thus no surprise that in later Babylonian traditions Numušda of Kazallu became closely linked with the name Mutiabal (as Mutabal). The observation of his star in a position above the star of Marduk determines the political fortunes of their cult-centres: Numušda's Mutabal (i.e. Kazallu) must have success at the expense of Marduk's Babylon.

At this point we may already conclude that a simple division of $E A E \mathrm{XX}$ into two recensions does not adequately report the ancient evidence. In Babylonia at least three recensions of §VII were extant in the first millennium, represented by (a) the early Neo-Babylonian MS S and its duplicate, Neo-Babylonian MS U (probably Babylon), (b) Neo-Babylonian MS a (probably Babylon) and (c) Late Babylonian MS IM (Sippar). None of them matches a fourth recension, (d) copied in Assyrian script at Nineveh (MSS D//L).

$\S$ VII Other collations. MS a rev. 3' (Rochberg-Halton 1988: 220): SI ZAG-šú TE- $m\left[a\right.$; MS D rev. $5^{\prime}$ (p. 203): ${ }^{`}$ ig-mur ${ }^{1}$ is more probably ${ }^{\top} \mathrm{ZI}-m a^{1}$. MS S rev. 2 (p. 204): ig-mur is also wrong here; read e-li. MS L 13' (p. 203): K]A $\times$ MI-šú

\section{Month VIII. Arahsamna}

\$VIII Protasis. MS IM 17-20. In the eclipse protasis of this section the text of MS IM is duplicated by the two other Neo-Babylonian sources, MS a (probably from Babylon) and MS e (a seventhcentury excerpt tablet from Ur) and by Neo-Assyrian MS Z (Aššr). The early Neo-Babylonian source MS S, on the other hand, has the directions "above" and "below" transposed:

$\left[{ }^{12}\right.$ (If)] on 14th Arahsamna (the moon god) brings about an eclipse and in [his eclipse] the god becomes dark [on the side] east below and [clear] on the side west above, ${ }^{13}$ a north wind (blows), in the middle watch he sets out (illik) and [in the dawn] watch he reaches halfway, and his cusps are [jabbing] the sky: ${ }^{14}$ observe the eclipse of [the god] whose cusps in his eclipse [were] jabbing the sky, and [keep] in mind the north wind.

EAE XX §VIII protasis MS S rev. 12-14

Neo-Assyrian MSS D, N and P are witness to very similar versions of the protasis, but their fragmentary state does not allow complete knowledge of their text. MS D (Kuyunjik) has igmur where early Neo-Babylonian MS S and Late Babylonian MS IM and duplicates all have illikma, so that it refers to an eclipse that sees out the middle watch, perhaps without continuing into the dawn watch. As they stand now, and leaving aside variants in spelling, the fragmentary MSS N (Nineveh) and $\mathrm{P}$ (Aššur) agree with both MS S and MS IM, so that this protasis does not determine to which recension they belong.

\$VIII Apodosis. MS IM 21-3. The text states that this eclipse omen concerns the city of Eridu; by this time Eridu was uninhabited and its name understood to signify Babylon. In the apodosis MSS IM and e bear witness to essentially the same text, from which the fragmentary MSS D, N, $\mathrm{P}, \mathrm{Z}$ and a do not deviate in any significant way. MS S begins with other material and then gives the prediction for Eridu, as follows:

$\left[{ }^{15}\right.$ DIŠ ina ITI.AP]IN MIN LÚ.NÍG.TUK šá É.BI $i$-šá-ri $\left[\check{s}\right.$ illaku] UG ${ }_{7} r i$-is-ba-tum GÁL.[MEŠ ${ }^{16}$ ina š]

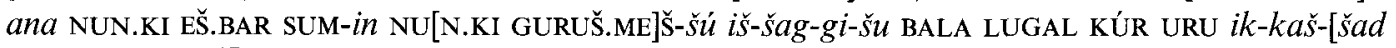
LUGAL LÁ-mu ${ }^{17}$ LUGAL $\left.q\right] \dot{a}-d u$ IM.RI.A-šú GAZ DUMU LUGAL z[I.MEŠ-šú KAR]-er

EAE XX §VIII apodosis MS S rev. 15-17

[ ${ }^{15}$ (If) in] Arahsamna ditto: a rich man will die though his household prospers; there will be brawls. [ ${ }^{16}$ Therein] a prediction is given for Eridu: the [menfolk] of Eridu will be slaughtered, the king's reign will change, the city will be taken, [the king will be captured, ${ }^{17}$ the king] will be put to death along with his family, but the crown prince will [escape with his] life. 
The extra material consists of an abbreviated protasis and an apodosis of the kind characteristic of second-millenium lunar-eclipse omens. Similar extra omens occur in $\$ \S I I-V I$, IX-X and XII of MS S and will be discussed below, in the concluding section.

$\S$ VIII Supplementary omen. MS IM 23-4. After the eclipse omen, a short supplementary omen is interpolated. In MS IM this concerned a conjunction of Venus with the moon on 14th Nisannu. MSS N, P, Z and a also preserve fragmentary traces of the same omen at this point; the only significant variant is offered by MS Z, which gives the date as 15th Nisannu. MS S again stands out as different, citing the month Arahsamna, probably because this was the month at issue in the immediately preceding eclipse omen. It differs in other details too:

ina ITI.APIN UD.14.KAM ${ }^{\mathrm{d}}$ dili-pát ana Š̉̀ $30 \mathrm{KU}_{4}$-[ma ana ZAG-šú È ${ }^{18}$ ZÁH] URU $u$ ÙG.MEŠ-šú GìR KÚR ana KUR [GAR-an?]

EAE XX $\S$ VIII supplementary omen MS S rev. 17-18

(If) on 14th Arahsamna Venus enters the moon [and comes out on its right side: ${ }^{18}$ destruction of ] a city and its people; an incursion of the enemy [will occur(?)] in the land.

$\S$ VIII Scholia. A single item of commentary relates to the protasis of the lunar-eclipse omen. It is preserved on the newly available Late Babylonian commentary from Uruk:

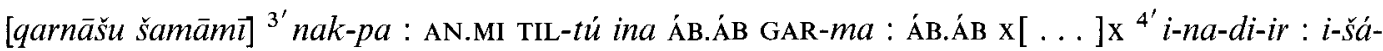
an-ni:

Uruk IV 162 rev. $3^{\prime}-4$

["His cusps] are jabbing [the sky"]: (it means the moon god) brings about a total eclipse among the Pleiades; the Pleiades = [ . . ]; "(if) it becomes eclipsed" (means) it changes shape.

The topic under comment is common to all sources and does not determine which of the variant omens of §VIII was known to the commentator.

At least three recensions of the text are visible in this section of $E A E X X$, represented respectively by (a) early Neo-Babylonian MS S, (b) Neo-Assyrian MS D (Kuyunjik), and (c) Late Babylonian MS IM and duplicates.

$\S$ VIII Other collations. MS D rev. 13' (Rochberg-Halton 1988: 206): šar-r]u? (not LUGA]L) ik-kám$m u$; MS N 2' (p. 205): i] $z$ - ${ }^{\top} k u^{\prime} ; 4^{\prime}-5^{\prime}$ (p. 206): KÚR-ir; MS P 2' (p. 205): i] z-ku IM.SI.S[Á; 6' (p. 206): BAL]A ' ${ }^{L}$ UGAL ina-kir ${ }^{7}$ UR[U; 8': LU]GA[L?; MS S rev. 13 (p. 207): $n[a-a k-p a]$; MS Z iii $18^{\prime}$ (p. 218): $\check{s} a-m[a-m i n] a k-p a$ DINGIR [ . . ], $19^{\prime}$ IM.KU[R.RA is doubtful (IM.S[I.SÁ is expected but not confirmed); 20': EŠ.BAR NUN.KI [ . . ] ]; 22': ‘KAR-er ${ }^{\prime}$ ina ITI.BÁRA UD.15.KÁM M[UL.

\section{Month IX. Kislimu}

$\S I X$ Protasis. MS IM 25-9. In the protasis there is again a distinction (as in §VIII) between one recension that describes the eclipse beginning "above" and clearing "below" and another that has these adverbs transposed. Of the eight manuscripts preserving text of this section, MS IM from Sippar is the most complete. As usual, its eclipse begins "above". Three Neo-Assyrian tablets, MSS M (Nimrud), P and Z (both Aššur), and an excerpt tablet from Kuyunjik (MS f) all agree with the protasis preserved on MS IM; two others, MSS D and N (also Kuyunjik), have such scant remains of §IX that they cannot be restored one way or the other. Neo-Babylonian MS a omits this section. It is again the oldest source, early Neo-Babylonian MS S, in which the eclipse begins "below"; this manuscript also offers an abbreviated version of the procedural clauses:

[ ${ }^{19}$ ( If ) on] 14th [Kislimu] (the moon god) brings about an eclipse and in [his] eclipse the god becomes dark [on the side] north below and [clear] on the side south above, $\left[{ }^{20} \mathrm{a}\right.$ west wind (blows),] in the dawn watch he reaches halfway, (and) [his] right cusp [is] curled: ${ }^{6}$ observe the

\footnotetext{
${ }^{6}$ Reading [kap]sat: see the collation of MS S rev. 20 at the end of this section.
} 
eclipse of the god who in his eclipse his right cusp was curled, and [keep in mind ${ }^{21}$ the west wind.]

EAE XX §IX protasis MS S rev. 19-21

$\S I X$ Apodosis and summary. MS IM 29-32. In her edition of \$IX Rochberg presented MS S as the only available source for the apodosis; the excerpt tablet MS f she treated on a different page (Rochberg-Halton 1988: 223). Following the identification of MS IM, and the publication in the 1990s of the tablet from Nimrud (MS M =CTN IV 5) and the Late Babylonian commentary tablet from Uruk (Uruk IV 162), more can now be said about this apodosis. The omen is stated to concern the city of Dēr. MSS M and IM present essentially the same text of the apodosis, which falls into two parts, concerning (a) the fate of Dēr and (b) a predicted movement of Venus. The two texts are only distinguished by an error of haplography in MS M, which for ul ultabbar reads $u l$-tab-bar (CTN IV 5 iv 8 ), without negation and thus conveying the opposite fate for the king: "he will live long". The older manuscript, MS S, offers a variant version, beginning with standard phrases not connected with Dēr. Since the published edition of MS S is faulty at this point and the new sources help with our understanding of it, the apodosis is given in full:

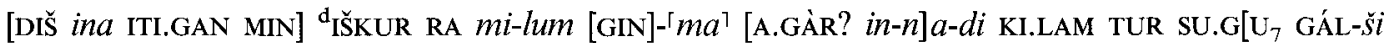
${ }^{22}$ ina Š̀̀ ana BÀD.A]N.KI ES̆.BAR SU[M-(in) LUGAL BÀD.A]N.KI BA.UG $7_{7}-m a$ KUR-su SI.SÁ-er šar-r $[u-u t$ KUR $23 \ldots] \times$ x x[ $\left.{ }^{2}(\mathrm{x}) \times \mathrm{E}\right] \mathrm{N} . \mathrm{NUN} \mathrm{MURUB}_{4}$.BA ina-țal DINGIR $e$-li ma-šá-[li GIN]

EAE XX §IX apodosis MS S rev. 21-3

[ (If ) in Kislimu ditto:] Adad will rampage. An inundation will come and [arable land(?) will be] left uncultivated(?). Commerce will dwindle. [There will be] famine. [ ${ }^{22}$ Therein] a prediction is given [for] Dēr: [the king of] Dèr will die, but his land will prosper; the kingship [of the land ${ }^{23}$ will endure. Venus] . . . will be visible in the middle watch. The god [went] on beyond the halfway point.

This passage has been restored from the Neo-Assyrian excerpt tablet MS $f$ (Kuyunjik), which holds a version of the apodosis that is neither exactly that of MS S nor that of MSS M//IM. Some of the spellings are unusual:

ina ŠÀ BÀD.AN.KI EŠ.BAR SUM ${ }^{14}{ }^{14}$ ÀD.AN.KI KI. ${ }^{\top}$ TUŠ-šu $q u r^{7}-r u-u b$ LUGAL BÀD.AN.KI KUR-su $u$-še$e s ̌$-šer ${ }^{15} \check{s} a r-r u$-ut KUR $u$-lab-bar AN.BAD $\left(={ }^{\mathrm{d}}\langle\right.$ dili $\rangle$-pát?) DA ni-ri ellil (50) na-wi-ru-ma iz-za-

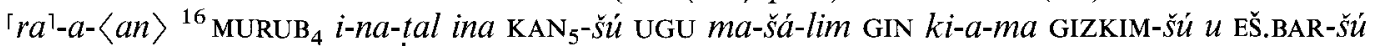

EAE XX §IX apodosis MS f obv. 13-16

The prediction is given for Dèr: ${ }^{14}$ the resettling of Dēr is at hand, the king of Dēr will bring his land to prosperity, ${ }^{15}$ the kingship of the land will endure. Venus(?) will be shining brightly alongside the Yoke of Enlil and ${ }^{16}$ will be seen in the middle "band". (The god) in his eclipse went on beyond the halfway point: thus his portent and prediction.

$\S I X$ Scholia. The planetary prediction is itself partly illuminated by the Late Babylonian commentary tablet from Uruk:

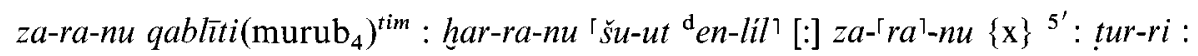

Uruk IV 162 rev. $4^{\prime}-5^{\prime}$, coll. F. Reynolds

The "middle zarānu" is the Path of the Enlil-Stars; zarānu means "band".

The presence here of the phrase zarān qablīti demonstrates that the commentator knew an apodosis like that of MSS IM//M.

Taking account of all sources, this section of $E A E \mathrm{XX}$ again suggests the existence of at least three recensions, represented respectively by (a) the early Neo-Babylonian source MS S, (b) the Neo-Assyrian excerpt tablet MS f, and (c) the Late Babylonian Sippar tablet MS IM and its duplicates from Neo-Assyrian cities. 
$\S I X$ Other collations. MS D rev. 15' (Rochberg-Halton 1988: 206) = catch-line: . . AN.T]A KAN $5^{-}$

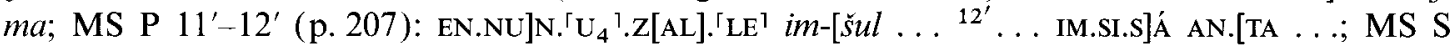
rev. 20 (p. 208): ZA[G-šú kap]-șa-át DINGIR.

\section{Month X. Tebētu}

$\S X$ Protasis. MS IM 33-7. Six manuscripts bear witness to the protasis of $\S \mathrm{X}$ : early Neo-Babylonian MS S, Neo-Assyrian MSS C (Kuyunjik), M (Nimrud) and Q (Aššur), Neo-Babylonian MS a and Late Babylonian MS IM. Of these, MSS C, Q and a preserve only a few signs. MSS M and IM agree word for word. As becomes clear from the statement at the end of its apodosis (1.30, quoted below), MS S disagrees as to the duration of the eclipse. It differs also in that it must have provided a fuller version of the procedural clause that exactly matched the observation of the portent. The protasis of MS S reads as follows:

[ ${ }^{24}$ I (If) on] 14th [ Ṭebētu] (the moon god) brings about an eclipse and [in his eclipse the god] becomes dark [on the side east above] and [clear] on the side west below, $\left[{ }^{25}\right.$ a] west wind (blows), in the dawn watch he [begins (the eclipse) but does not bring it to an end, (and) his cusps are of equal size - the one not growing] too fat nor the other too thin - [observe the eclipse of ] the god whose cusps in his eclipse $\left[{ }^{26}\right.$ were of equal size - the one] did not grow too fat nor the other too [thin - and keep] in mind the west wind.

$E A E \mathrm{XX} \S \mathrm{X}$ protasis MS S rev. 24-6

$\S X$ Apodosis and summary. MS IM 38-41. MS a having petered out, five sources are extant for the apodosis. The apodosis relates to Subartu. The extant manuscripts exhibit variation in:

(a) whether the omen is stated to be for Subartu and Gutium (so MS IM) or for Subartu alone,

(b) what the king of Subartu does, whether, as in MS IM, he attacked and looted, mäta ikaššad mäta išallal, or made peace, mātäti isallim (these variants arose easily by haplography in logographic writing, where the former is written KUR KUR-ád KUR $i$-šal-lal and the latter KUR.KUR $i$-sal-lim), and

(c) the synopsis of the protasis at the end, which reflects variant statements of the eclipse's duration in the protasis or even conflicts with the protasis (so MS S).

Here MS Q agrees with MS IM in all particulars; MS M, however, differs from MS IM in matters (a) and (b). MS C differs on all three counts; MS S probably agrees with MS C, but damage intervenes to prevent full knowledge of what, in its text, the king of Subartu did. In addition, MS S interpolates other apodoses before the material about Subartu. Rochberg's transliteration of MS Q is marred only by a single misreading (see the collations at the end of the section). Collated transliterations of both MS S and MS C follow, along with MS M, which was unavailable at the time of Rochberg's edition. They are given in order of increasing divergence from the text of MS IM:

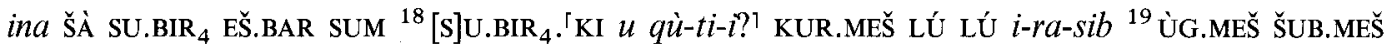
$a l$-ma-na-a-tu i-min-da ${ }^{20}{ }^{2}$ LUGAL $^{1}$ SU.BIR 4 .KI KUR.KUR $i$-sal-lim DINGIR šá UGU ma-šá-li [GIN]-ku $\left[{ }^{21} k i\right]$-a-am GIZKIM-š́ Eš.BAR-šú

$E A E \mathrm{XX} \S \mathrm{X}$ apodosis MS M iv 17-21

A prediction is given for Subartu: ${ }^{18}$ Subartu and Gutium will be captured; man will smite man, ${ }^{19}$ people will perish, widows will proliferate; ${ }^{20}$ the king of Subartu will make peace with the lands. The god who [went] on beyond halfway: thus his portent and prediction.

ina ŠÀ SU.BIR ${ }_{4} . \mathrm{KI}$ EŠ.BAR SUM-in [SU.BIR ${ }_{4} . \mathrm{KI}\left(u\right.$ gu-ti-um.KI) KUR.MEŠ] ${ }^{3}{ }^{\prime}$ LÚ LÚ $i$-ra-sib ÙG.MEŠ ŠUB.MEš [al-ma-na-a-tu i-min-da] ${ }^{4^{\prime}}$ LUGAL SU.BIR $_{4}$.KI KUR.KUR $i$-sal-lim DINGIR $\check{s} a i$-[na KAN $_{5}-$ šú SI.MEŠ-šú? mit-ḩa-ra-ma?] ${ }^{5^{\prime}}$ EN.NUN.MURUB ${ }_{4}$.BA SAR-ma la ú-qat-ti ki-a-a[m GIZKIM-šú $(u)$ EŠ.BAR-šú]

$E A E \mathrm{XX} \S \mathrm{X}$ apodosis MS C ii $2^{\prime}-5^{\prime}$

A prediction is given for Subartu: [Subartu (and Gutium) will be captured; ] ${ }^{3}$ man will smite man, people will perish, [widows will proliferate; ${ }^{4}$ the king of Subartu will make peace with 
the lands. The god whose [cusps(?) in his eclipse were equal(?)] ${ }^{5}$ began (the eclipse) in the middle watch but did not bring it to an end: thus [his portent and prediction.]

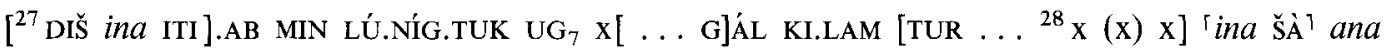

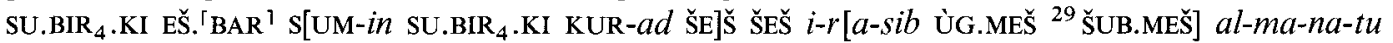
$i$-min-da L[UGAL SU.BIR ${ }_{4}$.KI] 'KUR KUR' [i-sal-lim? DINGIR šá $i$-na $\mathrm{KAN}_{5}$-šú SI.MEŠ-šú? ${ }^{30}$ mit-ha-

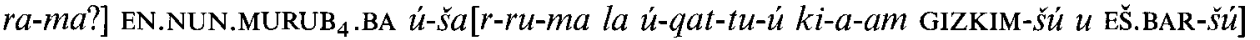

EAE XX $\S \mathrm{X}$ apodosis MS S rev. 27-30

[ ${ }^{27}$ I(If) in] Ṭebētu ditto: a rich man will die, there will be [ . . ., ] commerce [will dwindle ... ${ }^{28}$... . ] A prediction is [given] for Subartu: [Subartu will be captured;] ${ }^{3^{\prime}}$ brother will [smite] brother, [people ${ }^{29}$ will perish,] widows will proliferate; the [king of Subartu will make peace(?) with] the lands. [The god whose cusps(?) in his eclipse ${ }^{30}$ were equal(?) and who] began (the eclipse) in the middle watch [but did not bring it to an end: thus his portent and prediction.]

$\S X$ Scholia. This omen is also the subject of a fragmentary section of the Late Babylonian commentary tablet BM 41053 (rev. 1'-5', ed. Rochberg-Halton 1988: 209 fn. 1). A better-preserved (but different) exposition is given by the more recently published commentary from Uruk. It reads as follows:

DIŠ ina ITI.AB UD.14.KAM AN.MI GAR-ma SI.MEŠ-šú 1-et la ik-bir 1-et la iq-tin ${ }^{6}{ }^{\prime}$ MAš hab-rat : ina ÁB.NAGAR AN.MI GAR-ma : EN ITI-šú : ÁB.SUHUR.MÁŠ : ÁB.SUHUR.MÁŠ : KUR SU.BIR ${ }_{4} \cdot \mathrm{KI}^{{ }^{7}} u$ gu-ti-

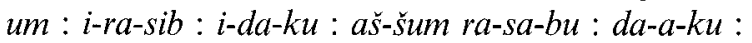

EAE XX §X commentary, Uruk IV 162 rev. 5'-7'

"q(If) on 14th Tebētu (the moon god) brings about an eclipse and, as regards his cusps, the one does not grow too fat nor the other too thin": (this means) a half moon; "(If) an eclipse takes place in the Crab constellation": the "lord" of its month is the Goat-Fish constellation, the Goat-Fish constellation = Subartu and Gutium; irassib ("he will smite") means "he will kill" because rasābu means "to kill".

This passage of commentary cites an abbreviated version of the protasis and then makes three comments. The first is that a partially eclipsed moon with cusps of equal size can be treated as the equivalent of a half-moon. The second asserts that a lunar eclipse on 14th Tebetu (X) is the counterpart of an eclipse in Cancer (IV), that the constellation governing Tebetu is Capricorn $(\mathrm{X})$, and that this constellation signifies the countries Subartu and Gutium. Thereby the protasis of $E A E \mathrm{XX} \S \mathrm{X}$ is connected with its the apodosis, a common goal of commentaries on omen texts. Finally, the rare verb irassib is elucidated by reference to a common synonym. The pairing of Subartu and Gutium indicates that the commentator was familiar with an apodosis like those preserved on MSS IM//Q and M, rather than that found on MS S, where the text is broken but there is certainly not enough space for both toponyms.

At least three recensions are visible in $\S \mathrm{X}$, represented respectively by (a) early Neo-Babylonian MS S, (b) Neo-Assyrian MS C (Kuyunjik) and (c) Late Babylonian MS IM (Sippar) and its near duplicates, Neo-Assyrian MSS Q (Aššur) and the slightly divergent M (Nimrud).

$\S X$ Other collations. MS a iii 21' (Rochberg-Halton 1988: 220, 20'): [DIš ina ITI.A]B U[D.14.KAM; MS Q iv 5' (p. 210): for ... ] ' 'IGI'.LÁ read KUR $i$-š]al-lal.

\section{Month XI. Šabātu}

$\$ X I$ Protasis. MS IM 42-7. The protasis of this omen is extant on five main manuscripts: early Neo-Babylonian MS S, Neo-Assyrian MSS C (Kuyunjik), M (Nimrud) and Q (Aššur), and Late Babylonian MS IM (Sippar). They are joined by a Neo-Babylonian tablet probably from Babylon, MS b. MSS M and Q bear essentially the same protasis as MS IM, which is restored from them. MS C adds innamir between the phrases itti Šamaš and qarnāšu šamê nakpāa (IM 44// M iv $24 / / \mathrm{Q}$ iv $8^{\prime}$ ), making two clauses of one: "(if the moon god) is observed in the company of the sun (and) 
his cusps are jabbing the sky". It also must have held more than simply tammarma between ina UD.28.KAM and attalu qurrub (IM 45-6// M iv 26//Q iv $9^{\prime}$ ). The tablet is damaged at this point but collation suggests an explicit object (Rochberg-Halton 1988: 211, MS C ii $8^{\prime}-9^{\prime}$ ): ina UD.28.KÁM DIN[GIR.(30) ina rabê-š́? tammar(igi)-ma] ${ }^{9 '}$ attalû qitrub "On the 28th day [you shall observe the (moon)] god [as he rises(?)] (to see if) an eclipse is at hand". MS S is increasingly damaged; the length of text lost in the breaks suggests that (a), like MS C it also included an explicit object before tammarma but (b), unlike all the other witnesses to this protasis, it did not include the phrase qarnāšu šamê nakpā. Assuming also that it agreed with MS C in other particulars, this is its version of the protasis:

[ ${ }^{31}$ I(If) on] 14th Šabātu (the moon god) brings about an eclipse and [in his eclipse the god] becomes dark [on the side south above and clear on the side east below, ${ }^{32}$ a north wind (blows),] he begins (the eclipse) in the dawn watch [and is still visible at sunrise, he does not] cover [all of the "emblem"] and disappears: on the 28 th day ${ }^{33}$ observe the (moon) god as he rises(?)], (to see if an) eclipse is at [hand: he will rise, be red] and show you an eclipse: observe [the eclipse of] the god who in his eclipse [became visible and disappeared,] ${ }^{34}$ and [keep in mind the] north wind.

$E A E \mathrm{XX} \S \mathrm{XI}$ protasis MS S rev. 31-4

$\S X I$ Apodosis and summary. MS IM 48-53. The omen is stated to concern Babylon. In the apodosis the six manuscripts extant for the protasis are joined for the last two lines by a Neo-Babylonian fragment from Uruk, MS R. MSS C, M and Q are again very close to the text of MS IM; the only significant variants are a preference for qurrub in MSS IM, M and Q against synonymous qitrub in MS C (already seen in the protasis), and MS Q's omission from the final summary of ittašu, which was probably inadvertent. MS R probably matches MS IM (read in 1. 1': B]ALA!? E.KI 'úrim'.KI $i k$-kim $\{\mathrm{x}\}$ "Ur will steal the hegemony(!) of Babylon"). The older source, MS S, differs in more respects. If correctly restored, it reports bad news for Babylon, and indeed the entire world (represented by the "four nations"), ${ }^{7}$ but then adds an additional, non-calendrical omen which signifies instead a favourable outcome:

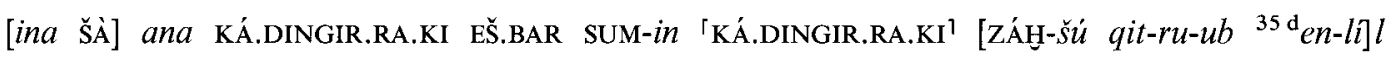
KUR.KUR ka-l[i-šli-na ittazar KU]R.KUR LÍMMU.MEŠ ina pu-ḩur DINGIR.MEŠ GAL.MEŠ $a$-šab ŠU[B-

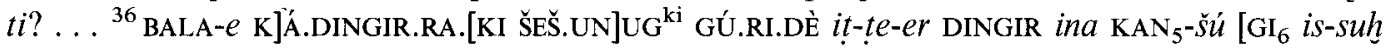
${ }^{37}$ ILLU ina ÍD] ŠÈG ina AN GIN-ni EBUR SI.SÁ dam-qá-tum GAR-[na]

$E A E \mathrm{XX} \S \mathrm{XI}$ apodosis MS S rev. 34-7

[Therein] a prediction is given for Babylon: [the destruction] of Babylon [is near; ${ }^{35}$ Enlil has reviled] all the lands: the four nations in the assembly of the great gods, dwelling amid [ruination(?) has been decreed for them(?). $\left[{ }^{36} \mathrm{Ur}\right.$ ] will take away from there ${ }^{8}$ [the hegemony of ] Babylon. (If ) [night elapses] while the god is in eclipse: $\left[{ }^{37}\right.$ floods] will come [in the rivers, ] rains in the sky, the harvest will be a success, good fortune will occur.

The Neo-Babylonian tablet MS $\mathrm{b}$ also has text that deviates far from the recension represented by MS IM but, while it also adds a favourable prediction, in other respects it does not appear to agree with MS S either. The passage runs as follows:

$[\ldots]^{3^{\prime}}$ GIG-tú IGI-mar den-[lil ... ${ }^{4^{\prime}}$ BALA-e KÁ.DINGIR.RA.[KI . . . ] ${ }^{5^{\prime}}$ ina ITI.zíz A.KAL ina ÍD ${ }^{\prime}{ }^{\prime}$. [AN ina AN-e GÁL.MEŠ? ( . . . )]

EAE XX §XI apodosis MS b rev. 3'-5'

$[\ldots]^{3^{\prime}}$ will experience trouble. Enlil [ . . ]. ${ }^{4}$ The hegemony of Babylon [Ur will steal(?) $(\ldots)]{ }^{5^{\prime}}$ In Šabātu [there will be] inundation in the river, rain [in the sky(?) ( . . ) ]

\footnotetext{
${ }^{7}$ The "four nations" are presumably those countries that in celestial divination were signified by the four cardinal points of the compass: Akkad, Elam, Amurru and Subartu (see further Rochberg-Halton 1988: 52-5).
}

\footnotetext{
${ }^{8}$ The word written GÚ.RI.DÈ is understood as an adverb of direction in the light of such lexical equations as gú.ri.ta $=$ ul-la-nu-um "from there", iš-tu an-ni-iš "from here" (MSL IV $66: 11 ; 201: 380$ ).
} 
$\S X I$ Scholia. The commentary from Uruk makes four observations on the eclipse omen $E A E$ $\mathrm{XX} \S \mathrm{XI}$ :

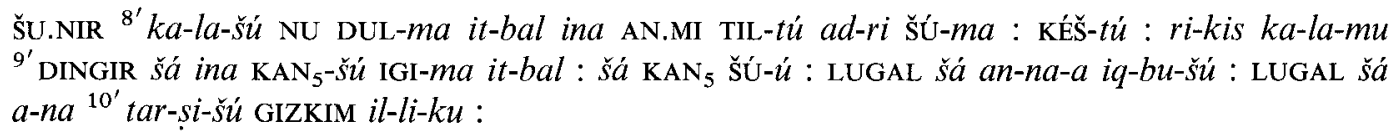

EAE XX §XI commentary, Uruk IV 162 rev. 7'-10'

"(If) he does not cover all of the 'emblem' and disappears": (this means) in a total eclipse he set in obscurity; " "bond" = bond of everything; "the god who in his eclipse became visible and disappeared" (means) who set while eclipsed; "the king to whom (Enlil) said "Yes"" (means) the king in whose time the portent happened.

The first three of these comments refer to the protasis. The first explains what is meant by the statement about the moon's face (šurinnu "emblem") not being fully covered: the moon has set while totally eclipsed. This seems to be the reverse of the expected explanation; perhaps the text is defective (e.g. for ina attalê lā gammarti "while partially eclipsed"). The second comment elucidates a word, either rikistu or kisirtu, if that is how KÉš-tú should be transcribed, that is not preserved in the protases that are extant; it can be reconciled with the surviving text if it falls in the broken passage of the protasis represented by MSS S and C, where it could only be the object of tammar. However, neither rikistu nor kisirtu matches the trace of the beginning of this word visible on MS C, where we have read as ila. Whatever the solution to this problem, the explanation "bond of everything" suggests a cosmological interpretation (on the cosmic "bonds" see Horowitz 1998: 265). The third comment explains the summary, which one would have thought lucid enough to need no such comment. The final comment identifies who in the apodosis is meant by the king approved by Enlil. The presence of this topic makes it very likely that the commentator knew an apodosis like that on MSS IM//M//Q and MS C, for the phrase in question does not seem to appear on MS S.

The eclipse omen of $\S \mathrm{XI}$ thus also survives in at least three recensions: (a) that of the oldest source, early Neo-Babylonian MS S, (b) that of Neo-Assyrian MS C (Kuyunjik) and (c) that of Neo-Assyrian MSS M (Nimrud) and Q (Aššr) and Late Babylonian MS IM (Sippar). Recensions (b) and (c) are closely related.

$\S X I$ Other collations. MS C ii 12' (Rochberg-Halton 1988: 211): BIR-ša qit-ru-ub, DÙ.A.BI ' $i^{1}$-[ruur, 14': KAR-ki[m?]

\section{Month XII. Addaru}

$\S X I I$ Protasis. MS IM 54-7. Seven manuscripts of EAE XX provide the text of the protasis of §XII: the Middle Assyrian fragment MS Y (Aššur), early Neo-Babylonian MS S, Neo-Assyrian MSS C (Kuyunjik) and Q (Aššur), Neo-Babylonian MSS R (Uruk) and b (probably Babylon), and Late Babylonian MS IM (Sippar). MSS C and Q hold text that is essentially identical with the protasis of MS IM, except that where MS IM cites both west and east winds as blowing during the eclipse, MS Q has only the west wind; MS C is broken in both places where winds are cited, and what option it chose cannot be determined. Now fragmentary, MS R seems to present an anomalous version of the same protasis, with duration and direction transposed: as can be seen on Weidner's copy, the phrase idi iltāni eliš [i"adir] is clearly preceded by šăt-ur]ri ušarrima (Weidner 1954-6: Pl. 2 Uruk 159 1. 3', and see the collation at the end of the section). A more radical variant is MS S, which differs as to the direction of the eclipse and omits all reference to the lunar cusps. In this it is matched by MS b, apart from spelling variants. The text of both runs as follows:

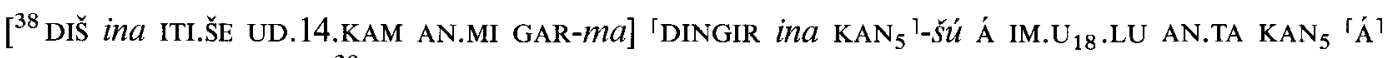
IM.KUR.RA KI.[TA $i z-k u^{39}$ IM.KUR.RA EN.NUN]. ${ }^{\top} \mathrm{U}_{4}{ }^{7}$.ZAL.LE TIL ina na-pa-ḩi-šú NU IGI-ir ina GAL-šú

\footnotetext{
${ }^{9}$ Reading ina attalê gammarti adri( $(\tilde{S})$ irbìma. For attalê gammarti, lit. "eclipse of completion", in other contexts see Rochberg-Halton 1988: 49 fn. 82, Brown and Linssen 1997:
} 
IGI-ir DINGIR ša ina $\mathrm{KAN}_{5}-\left[\right.$ šú ina MÚ-šú ${ }^{40}$ NU IGI-ru ina GAL-šú IGI-r] $u$ KAN $_{5}-\check{s ̌ u ́ ~ I G I-m a ~ I M . K U R . R A ~}$

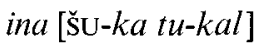

$E A E \mathrm{XX} \S \mathrm{XII}$ protasis MS S rev. $38-40$

${ }^{6}$ DIŠ ina ITI.ŠE UD.14.KAM AN.MI GAR-ma DINGIR ina ${ }^{1} \mathrm{KAN}_{5}{ }^{1}-\breve{s ̆ u}^{\circ}{ }^{\circ}{ }^{1}[\ldots]{ }^{7}{ }^{\prime}$ IM.KUR.RA

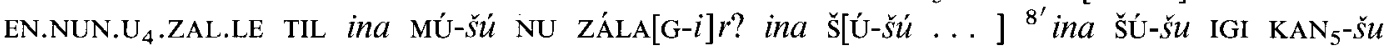
IGI.TAB-ma IM.KUR.RA ina ŠU- $k a t u-[k a l]$

$E A E \mathrm{XX} \S \mathrm{XII}$ protasis MS b rev. $6^{\prime}-8^{\prime}$

I(If) on 14th Addaru (the moon god) brings about an eclipse and in his eclipse the god becomes dark on the side south above and [clear] on the side east below, an east wind (blows), in the dawn watch he brings (the eclipse) to an end, he cannot be observed ${ }^{10}$ when he rises but can be observed when he sets: observe the eclipse of the god who in [his] eclipse [could not be observed when he rose but] could be observed when he set and keep in mind the east wind.

The last witness is the reverse of Middle Assyrian MS Y, which gives a glimpse of a recension of $E A E \mathrm{XX} \S \mathrm{XII}$ in the late second millennium. Rochberg's transliteration (Rochberg-Halton 1988: 217-18) fails to convey that the text at this point is written in uncharacteristically narrow columns. Once this is realized, the protasis can be transliterated thus:

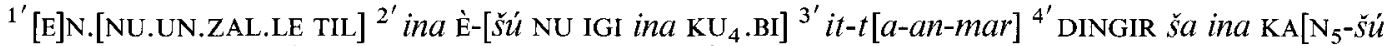

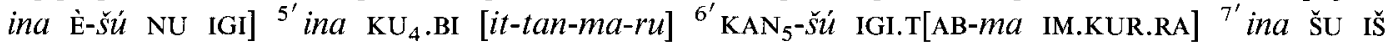
(= DAB!? for $t u k a ̂ l l !)$

\section{$E A E \mathrm{XX} \S \mathrm{XII}$ protasis MS Y rev. 1'-7'}

$\left[\ldots{ }^{1}\right.$ (the moon god) brings (the eclipse) to an end in the] dawn [watch, and ${ }^{2^{\prime}}$ cannot be observed] when he comes out but ${ }^{3^{\prime}}$ can be [observed when he goes in:] ${ }^{6^{\prime}}$ observe the eclipse of $4^{\prime}$ the god who in [his] eclipse [cannot be observed when he comes out but ${ }^{5^{\prime}}$ can be observed] when he goes in and ${ }^{7^{\prime}}$ keep in mind(!) [the east wind.]

Apart from the corrupt final line, this text is fundamentally the same as that preserved on MSS $\mathrm{S} / / \mathrm{b}$. The only substantive difference is the choice of verbs to describe the moon's rising and setting:

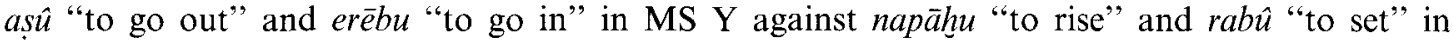
MSS S / b.

$\S X I$ Apodosis. MS IM 58-60. The omen is stated to pertain to the west (Amurru). The apodoses show considerable variety. Neo-Assyrian MS C (Kuyunjik) falls silent after two fragmentary lines but still manages to pose an enigma, for we are unable to reconcile with any better-preserved manuscript the traces of the two signs preserved in its last line (see the collations at the end of the section). Neo-Assyrian MS Q (Aššur) offers a protasis that duplicates Late Babylonian MS IM (Sippar) in all but minor points of spelling, with the exception of two substantive variants:

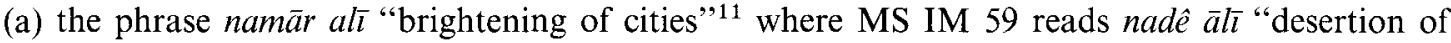
cities", and (b), as already noted, the correct phrase èma äli rihșu iššakkan "wherever there are cities, devastation will occur", where MS IM 60 has corrupted text, èma URU RA NUN iššakkan. Little of Neo-Babylonian MS R survives but, as in the protasis, it clearly offers a text unlike that of other sources:

A prediction is given for Amurru: $\left[{ }^{5^{\prime}} \ldots\right]$ s will die. Nations will devour one another $[\ldots$ EAE XX §XII apodosis MS R 4'-5'

In the protasis it was found that the older sources, Middle Assyrian MS Y (Aššrur) and early Neo-Babylonian MS S, held much in common, and that the tradition of MS S was represented

\footnotetext{
${ }^{10}$ If correctly read, the spelling NU ZÁLAG-ir in MS b is ostensibly la immir "he does not grow bright". Although this makes some sort of sense in the context of eclipse omens, we suspect that its presence is owed to an ancient misinterpretation of la innamir "he cannot be observed" (so MS S) as if from namāru "to grow bright" not nanmuru
}

\footnotetext{
"to be observed", and a consequent adjustment of the spelling.

${ }^{11}$ This obscure phrase has already occurred in the Sippar manuscript at §VII (IM 15). Rochberg read MS Q iv 23 [k]a-mar URU.MEŠ but it is clear from Weidner's copy (1954-6: Pl. 1) that space is lacking for this reading.
} 
in the mid-first millennium by Neo-Babylonian MS b. Here too MSS S and b are close: they both prefix the apodosis containing the prediction for Amurru with supplementary predictions, as MS $\mathrm{S}$ did in $\S \mathrm{VIII}-\mathrm{X}$. Their texts read thus:

$\left[{ }^{41}\right.$ DIŠ ina ITI.ŠE MIN] A.ZI.GA ina ÍD $i b$-ba-lu ib-bu-túu GÁL.MEŠ ÉRIN ma-'-du [imaqqut mahīru isehher ${ }^{42}$ nišu šerrī] -ši-na ana KÙ.BABBAR BÙR.MEŠ ina ŠÀ ana KUR [MAR.TU'.KI EŠ. BAR SUM-in

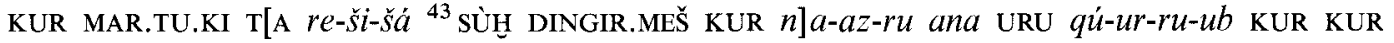

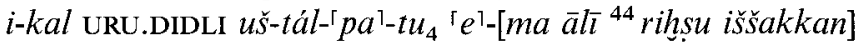

$E A E \mathrm{XX} \S \mathrm{XII}$ apodosis MS S rev. 41-4

$[\ldots]{ }^{9^{\prime}}$ IGI.NIGIN GÁL.MEŠ ÉRIN $m a-d u$ ŠUB- $u t$ KI.LAM TUR [Ü]G.MEŠ TUR.MEŠ-š $r i-n a$ ana KÙ.BABBAR BÚR.MEŠ ina ŠÀ K[UR MAR.TU.KI] ${ }^{10^{\prime}}$ EŠ.BAR SUM-in KUR MAR.TU.KI TA SAG-ša in-neššsi DINGIR.MEŠ KUR na-az-ru ana URU qit-ru-ub [KUR KUR i-kal] ${ }^{11^{\prime}}$ URU.DIDLI $u s ̌-t a ́ l-p a-t u_{4}$ e-ma URU.DIDLI GìR.BAL GAR-an

$E A E \mathrm{XX} \S \mathrm{XII}$ apodosis MS b rev. $8^{\prime}-11^{\prime}$

[१(If) in Addaru ditto:] floods will dry up in the river, there will be starvation(?), ${ }^{12}$ many people will perish, commerce will dwindle, people will sell their babies for silver. [Therein] a prediction is given for the land of Amurru: the land of Amurru, from its top (down), will fall into chaos; the gods of the land are accursed, [city] will be close to city, nation will devour nation, cities will be sacked; wherever there are cities, devastation will occur.

Both sources report a corrupt text that lacks the subject of the phrase ana ali qurrub/qitrub "will be close to city". The solution is provided by the Middle Assyrian MS Y. This source does not include any preliminary material but tells the prediction against Amurru as follows:

ZÁH ${ }^{\circ} \mathrm{KUR}^{1} \mathrm{M}$ [AR.TU] ${ }^{8^{\prime}}$ ina rēši(SAG! tablet: KA)-ša in-né-[eš-ši ${ }^{9}{ }^{\prime}$ DINGIR.MEŠ KUR na-az-r[u!]

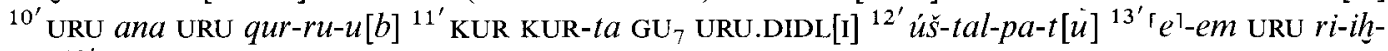
$s\left[u^{13^{\prime}} \mathrm{GA}\right] \mathrm{R}-a n$

$E A E \mathrm{XX} \S \mathrm{XII}$ apodosis MS Y rev. $7^{\prime}-13^{\prime}$

Destruction of the land of [Amurru, ${ }^{8^{\prime}}$ from its top (down) it will fall into [chaos; ${ }^{9^{\prime}}$ the gods of the land are accursed, ${ }^{10^{\prime}}$ city will be close to city, nation will devour nation, cities will be sacked; wherever there are cities, devastation will occur.

$\S X I I$ Supplementary omen and summary. MS IM 60-3. §XII of EAE XX is one of those sections that append a supplementary omen without obvious connection to lunar eclipses (see already $\$ \$$ VII and VIII). In this case the supplementary omen concerns the rising during daylight of the star of Papsukkal (var. Sipazianna = Orion).${ }^{13}$ As far as they are preserved, Neo-Assyrian MS Q (Aššur), now fragmentary, and Neo-Babylonian MS R (Uruk), which retains only a single phrase of this supplementary omen, do not differ greatly from the text handed down on Late Babylonian MS IM (Sippar), but they are not exact duplicates; for improved readings of MS Q see the collations at the end of the section. The supplementary omen appears on MSS S//b and Y as follows:

[MUL.SIPA.ZI.A]N.NA EN $n i-p i-i h{ }^{\text {d }}$ UTU GUB- $i z$ KI NAM.LÚ.U ${ }_{18}$.LU MÁšs. ${ }^{\ulcorner}$ANŠE ${ }^{1}$ ÁB.GU[D.HI.A $\ldots{ }^{45} \ldots$ KUR $i a-a r-r u-u] r$ ? ah-rat ÙG.MEŠ UG ${ }_{7}$.MEŠ DINGIR ina KAN $_{5}$-[̌̌ú EN.NUN.U 4 .ZAL.LE $\dot{u}$-gam-mir]

$E A E \mathrm{XX} \S \mathrm{XII}$ supplementary omen MS S rev. $44-5$

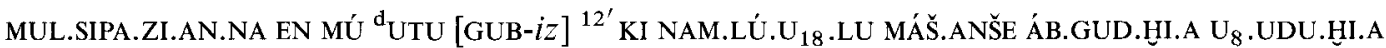
IGI-ir KUR $i a-a r-r u$-[ur] ${ }^{13^{\prime}} u h$-ḩu-rat ÙG.MEŠ UG 7 .MEŠ DINGIR ina KAN $_{5}-\check{s} u$ EN.NUN.U 4 .ZAL.LE [TIL] $E A E \mathrm{XX} \S \mathrm{XII}$ supplementary omen MS b rev. 11'-13'

\footnotetext{
${ }^{12}$ Combination of MSS $\mathrm{S}$ and $\mathrm{b}$ yields an equation IGI.NIGIN = ibbutu, unless they are variants in more than just spelling. The former calls to mind Sum. iginigin.na $=$ Akk. șud $p \bar{a} n \bar{l}$, a physical condition characterized by giddiness. Elsewhere in EAE XX MS S writes $i b$-bu-tú where other sources have ubbutu "starvation", as noted by
}

Rochberg-Halton 1988: 181 n. 2, 195 1. 5, 214 n. 4.

${ }^{13}$ For the equation of the messenger god Papsukkal with the constellation Sipazianna (Orion) in ${ }^{\mathrm{mul}}$ Apin and other texts, see Wiggermann 2001: $500 \$ 7$ and the references there cited. 
(If) the constellation Sipazianna is present until sunrise and is visible with humans, wild animals, cattle and sheep, the land will fall into panic, the posterity of the people will die. ${ }^{63}$ The god [completed] the dawn watch while eclipsed.

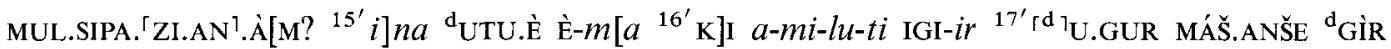

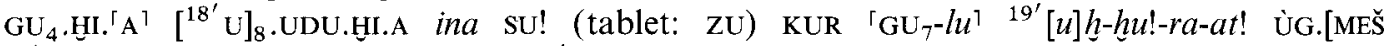
$\left.{ }^{20^{\prime}} \mathrm{UG}_{7} . \mathrm{MES}\right]$ DINGIR $\check{s} a$ ina $\mathrm{KAN}_{5}-\left[\check{s} u{ }^{21^{\prime}}\right.$ EN.NU].UN.USAN TIL-[mir]

$E A E \mathrm{XX} \S \mathrm{XII}$ supplementary omen MS Y rev. 14'-21'

(If) the constellation Sipazianna comes forth ${ }^{14^{\prime}}$ in the east and ${ }^{15^{\prime}}$ is visible(?) with mankind, ${ }^{16}{ }^{\prime}$ Nergal will devour wild animals, Šakkan will devour cattle and ${ }^{17^{\prime}}$ sheep throughout the land; ${ }^{18^{\prime}}$ the posterity of the people $\left[{ }^{20^{\prime}}\right.$ will die. The god completed ${ }^{21^{\prime}}$ the evening watch while eclipsed.

The various accounts of this omen hold no consensus as to where the boundary falls between the protasis and the apodosis. In Middle Assyrian MS Y the clause that pertains to humankind is placed in the protasis and that concerning livestock in the apodosis. In early Neo-Babylonian MS S and its duplicate, humans and livestock fall together in the protasis. Late Babylonian MS IM and its duplicates place humans and livestock in the apodosis. The phrasing of protasis and apodosis changed radically as different editors strove for meaning.

$\S X I I$ Scholia. This section as a whole is the subject of comment by the Late Babylonian commentary tablet from Uruk, Uruk IV 162. At this point it is supplemented by the more fragmentary tablet transliterated by Rochberg as EAE XX text k (Rochberg-Halton 1988: 227-8). Also from Uruk, MS $\mathrm{k}$ is Seleucid and dated by its colophon to about a century after Uruk IV 162. Nevertheless the two texts differ only in minor spelling variants, indicating that this was a commentary which had entered the scribal tradition as a text worthy of handing down. We give a transliteration with line-numeration according to the better-preserved exemplar:

DIŠ ina ITI.ŠE UD.14.KAM AN.MI GAR-ma SI.MEŠ-šú ina še-e-ri (sic) la $\{:\}^{11^{1}}$ in-na-at-ta-lu ina GAL-šú in-na-at-ta-lu : ina AN.MI TIL-tú šá LU[GAL?] ${ }^{12^{\prime}} \dot{u}$-nam-mi-ru ŠÚ-ú TA : i-na : 'papsukkal KUR-ma KI ${ }^{\mathrm{d}} \mathrm{UTU}$ GUB : ${ }^{\mathrm{d}} 30$ ina ${ }^{13}{ }^{\prime}$ ÁB(sup. ras.).SIPA.ZI.AN ana GENNA KUR-ma : AN.MI

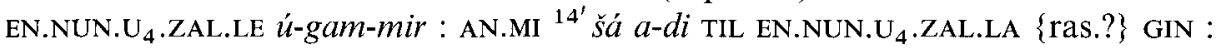

EAE XX §XII commentary, Uruk IV 162 rev. 10'-14'

$/ /$ MS k rev. $1^{\prime}-3^{\prime}$

" $q$ (If) on 14th Addaru (the moon god) [brings about] an eclipse and his cusps ${ }^{11^{\prime}}$ cannot be seen in the morning but can be seen when he sets": in a total eclipse in which (the moon god) lit up ${ }^{12}$ ' Regulus(?) (and) set; the sign $t a=$ "in"; "(If) Papsukkal rises and stands present with the sun": (it means) the moon god in ${ }^{13^{\prime}}$ the constellation Sipazianna caught up with Saturn; "(If the moon god in) eclipse completes the dawn watch" (means) an eclipse ${ }^{14}$ ' that went on until the end of the dawn watch.

This item of commentary sets out four pieces of information. First is a comment on the basic observation of the eclipse, which establishes an alternative, cryptic reading of the portent. Next (as deciphered here) is a lexical quotation that equates a Sumerian postposition with its Akkadian counterpart; though the preposition ina is written with the sign ta elsewhere in $E A E \mathrm{XX}$ (see 1.62 of MS IM), as well as routinely in EAE XXII, the equation has no immediate relevance to the passage under comment and its presence here may be a relic of a master's discursiveness or a pupil's inattention. Third is an explanation of the supplementary omen about the rising of Orion; this also gives an alternative interpretation of the portent. And finally a standard statement of an eclipse's duration is paraphrased in what may be less technical language. The third point cites the supplementary omen as it appears in Late Babylonian MS IM (Sippar) and not as it appears in MSS S $/ / b$ and $Y$.

Another tablet of commentary that bears on $E A E \mathrm{XX} \S \mathrm{XII}$ is Neo-Assyrian K 3145 (Kuyunjik), edited by Rochberg as Text $\mathrm{j}$ (Rochberg-Halton 1988: 225-6). The reverse contains only traces but read in 1. 9': e-ma URU ri-ih-sú GAR-a [n (coll.) "wherever there are cities, devastation will occur". 
$\S$ XII is remarkable for the independence of its manuscripts. MSS S and b have close affinities, despite the long interval that must separate them. Unsurprisingly, given the relatively early date of MS S, their text shows a close relationship to the Middle Assyrian MS Y. The Late Babylonian commentaries report a text very like that on MS IM and its near duplicates, Neo-Assyrian MSS $\mathrm{C}$ and $\mathrm{Q}$. Neo-Babylonian MS R deviates from all other manuscripts.

$\S X I I$ Other collations. MS C ii $17^{\prime}$ (Rochberg-Halton 1988: 213): IM.KU]R. ${ }^{[R A}{ }^{7}$; ii 18': ina Š̀ KU[R; ii 19': ] 'LA BE?'[; MS Q iv 22' (p. 213): re-ši-šá s[ùH]; iv 23': [n] a-mar; iv 25': 'e'-ma URU RA-su GAR-an d pap-sukkal [KUR-m]a ${ }^{\lceil\mathrm{KI}}$ (! tablet: UD?) ${ }^{\mathrm{d}} \mathrm{UTU}^{1} \mathrm{G}$ GUB-iz; iv $26^{\prime}$ (p. 214): [a]h-rat ÉRIN.MEš;

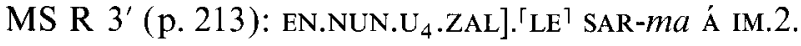

\section{Section of summary}

$\S X I I I$. MS IM 64-7. To the twelve sections on calendrical lunar-eclipse omens the recension represented by Late Babylonian MS IM (Sippar) adds a short passage of summary. This is damaged but seems to have consisted of three elements. First is a general statement that lunar eclipses at the full and half-moons are bad portents (IM 64). Next is a fragment of a sentence that we do not understand at present (IM 65); it may be related to the summary of Neo-Babylonian MS b, which mentions purussû (eš.bar) attalê (AN.MI) kalı̌šunu (dù.a.bi) "the predictions of all eclipses" (rev. 21', see Rochberg-Halton 1988: 221). Finally, the foregoing sections are summed up by their common denominator, eclipses that set in "above" and clear "below"; these eclipses the moon is said to reveal to the observer, along with their location and duration.

A similar summary is included only on the older source, MS S rev. 50, which is fragmentary (collations at the end of this section). The duplicating tablets of commentary from Late Babylonian Uruk add to our knowledge of this section of text. In combination they read as follows:

DIŠ AN.MI : ina UD.7.KAM UD.14.KAM UD.21.KAM ${ }^{\text {r.15' }}$ ana UGU IGI(so k, vaŕ.: SAL)-šú $u$ TIL-tú :

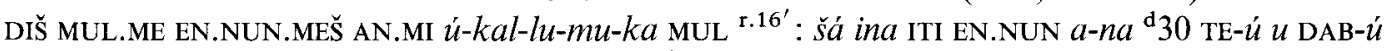
MUL.MEŠ ziq (so K, var: GAZ)-pi šá ina UGU ${ }^{\text {r.1 } 17^{\prime}}$ AN.MI ${ }^{\mathrm{d}} 30 \mathrm{GAR}$-an pi-šir ana Š̀̀ $t a-q a b-b i$ :

EAE XX §XII commentary, Uruk IV 162 rev. $14^{\prime}-17^{\prime}$

(coll. F. Reynolds) // MS k rev. $4^{\prime}-7^{\prime}$

"I (If the moon god brings about) an eclipse on the seventh, fourteenth (or) twenty-first day": ${ }^{15^{\prime}}$ with regard to his (first) sighting and termination. "IStars, watches, eclipse(s), he will show (!) you." 14 A star: ${ }^{16}$ that which in the month under watch approached the moon god and passed by; the culminating stars: those that are put(?) on top of the moon's eclipse. Therefrom you can pronounce an interpretation.

Not all is certain in this difficult passage and the translation is provisional. The first statement quotes in abbreviated form the protasis known to IM 64; the comment seems to assert that the date of an eclipse is determined by the date of its beginning and end. The dates cited in the quotation are not empirical but schematic; neither the seventh nor the twenty-first of a lunar month can witness a lunar eclipse. But impossible dates permeate $E A E$ and are not the problem here, which is that the commentator's assertion seems a little too obvious. In a calendar that starts a new day at dusk the observed phases of any given lunar eclipse, from first sighting to last, will all take place on the same date. Next is a quotation which uses terminology already encountered in EAE XX (MS IM 46 and 67): it is the moon that "shows" the observer the eclipse and its attendant circumstances. The third item of comment appears to be a definition of what is meant, in the context of lunar-eclipse omens, by kakkabu "star" and kakkabü ziqpi "stars of zenith", i.e. culminating stars. Finally, as the last comment on $E A E \mathrm{XX}$, the commentator asserts the fundamental basis of celestial observation: by observing lunar eclipses and other phenomena one can decode the warnings of the gods and take appropriate measures in response.

$\S$ XIII Other collation. MS S rev. 50 (Rochberg-Halton 1988: 215): U]D.14.[KAM] 'UD'.21.KAM GAR [.

${ }^{14}$ We take $u$-kal-lu-mu-ka as corrupt for $u k a l l a m k a$, as in MS IM 46 and 67 and parallels. 
Other text and colophons

$\S X I V$. MS IM 68. The Late Babylonian MS IM (Sippar) and the two commentaries from Uruk all end with §XIII. MS IM appends a simple rubric identifying the preceding text as the second half of the tablet and a short colophon recording the faithfulness of the copy. The commentaries hold a catchline, an elaborate rubric identifying the text, and long colophons. Catchline and rubric run as follows:

DIŠ ni-i-ri šá A.AB.BA ${ }^{18^{\prime}}$ a-dir dé-a a-dir : AN.MI ina ÁB.GU.LA GAR-ma șâtu u šūt pî ${ }^{19^{\prime}}$ malsūt iškar Enūma Anu Ellil ša libbi DIš ina nisanni ud.14.kam attalâ iškunma ${ }^{20^{\prime}}$ ilu ina (so k, var. om.) na'durīš al.til

Uruk IV 162 rev. $17^{\prime}-20^{\prime} / /$ MS k rev. $8^{\prime}-10^{\prime}$

"q (If) the Yoke Star of the Sea is obscure, Ea is disquieted": (the moon god) brings about an eclipse in the Great Constellation ( = Aquarius).

Commentary and oral explanations, passages read from the series Enūma Anu Ellil, from the part " $T$ (If) on 14th Nisannu (the moon god) brings about an eclipse and in his eclipse the god". Finished.

The last word of the rubric indicates that the tablets hold the complete text of the canonical Late Babylonian commentary on $E A E \mathrm{XX}$. Nevertheless, the catchline they provide is not the first line of $E A E$ XXI, which deals with a lunar eclipse on 14th Nisannu, starting in the south, but an omen of the Yoke Star and its explanation. The same omen probably occurs as the catchline of the fragmentary Kuyunjik commentary tablet MS j rev. 14' (Rochberg-Halton 1988: 227): DIS ' ${ }^{\text {MUL.ŠUdUN }}{ }^{1}$ A.AB.B[A] a-dir. The omen of the dim Yoke Star occurs elsewhere in EAE (ACh Ištar No. 21: 41; K 4166 ii 1', ed. Rochberg-Halton 1988: 272). Its connection with $E A E X X$ is also evident from Neo-Babylonian MS b (Babylon), where this and another omen about the Yoke Star are interpolated after $E A E X X$ §XII (MS b rev. 14'-17', ed. Rochberg-Halton 1988: 220-1). But that is not the whole evidence. Fragmentary versions of the same two omens survive in other sources of $E A E \mathrm{XX}$ : the early NeoBabylonian MS S and Neo-Assyrian MS Z (Aššur). What can be read runs as follows:

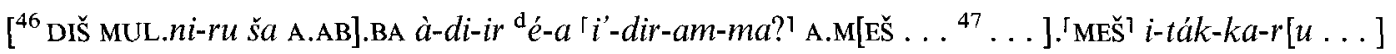
$\mathrm{x} \mathrm{x}[\ldots]$

$\left[{ }^{48} \mathrm{DIš} \ldots\right]$ à-di-ir $\left[\ldots{ }^{49} \ldots\right] \times \mathrm{x} \times \mathrm{x}[\ldots$

MS S rev. 46-9

[1'DIŠ MUL.ni-ru šá A.AB.BA] a-dir dé-[a ${ }^{1}$-a-dir A.MEŠ ina ÍD dal-hnu ${ }^{2}{ }^{\prime} \mathrm{SU}^{\prime} \mathrm{GU}_{7}$ GÁL-ši $]$ LUGAL.MEŠ $i-t a k-k[a !-r u \ldots]$

$\left[{ }^{3 \prime}\right.$ DIŠ MUL.ni-ru śá I]M.KUR.RA $a$-dir de $e$ n-líl i'-a-dir SA]R?.MEŠ $\left[i b-b a-l u^{4^{\prime}}\right.$ DINGIR.MEš $\left.i n a\right]$ SU KUR BAD.MEŠ [X X X.M]Ě̌? MI? X X [(x) X]

MS Z rev. ii 1'-4'

The text of this section of MS b is more accurately given by Rochberg but we repeat it for comparison with MSS S and Z:

${ }^{14^{\prime}}$ DIŠ MUL.ni-ru ša A.AB.BA $a$-dir dé-a $i^{\prime}$-a-dir A.MEŠ ina ÍD dal-hnu SU.GU 7 GÁL-ši LUGAL.MEŠ $i-t a[k-$ $k a-r] u{ }^{15}$ URU.DIDLI $u d-d a-a-t i$ IGI.MEŠ SU.GU 7 MÁŠ.ANŠE NAM.LÚ.U 18 .LU GÁL.MEŠ

${ }^{16^{\prime}}$ DIŠ MUL.ni-ru ša IM.KUR.RA $a$-dir ${ }^{\text {dé }} e n$-lil $i^{\prime}$-a-dir Ú.HI.A $a b$-lu DINGIR.DINGIR ina SU KUR BAD.MEŠ ${ }^{17^{\prime}}$ URU in-na-an-di URU in-na-id den-lil KUR.KUR SÙH ú

MS b rev. $14^{\prime}-17$

I(If) the Yoke Star of the Sea is obscure, Ea will be disquieted: river water will be turbid, famine will occur, kings will wage war on one another, cities will experience difficulties, famine will occur among livestock and men.

I(If) the Yoke Star of the East is obscure, Enlil will be disquieted: vegetation will dry up, the gods will withdraw from throughout the land. A city will be abandoned, a city will be praised. Enlil will reveal panic to the lands.

Hereafter MS Z adds two sections, the first of which is interpolated near the beginning of $E A E$ XX on other manuscripts, the second later in the series (see Rochberg-Halton 1988: 218-19 textual 
notes 1 and 2). In this it is duplicated by the fragmentary reverse of Neo-Babylonian MS T (Nineveh; see the collations below). MSS S and b have instead other material. First is a summary, essentially a variant version of the summary found on LB MS IM 66-7 and its duplicates (MSS S rev. $51 / /$ b rev. $18^{\prime}$ ). There follow two general "laws" relating eclipses to a prior darkening of the moon and sun (MSS S rev. 52//b rev. 19'-20'). Neo-Assyrian MS Z and Neo-Babylonian MS T conclude with the catchline of $E A E \mathrm{XXI}$; MS Z adds a colophon (broken away on MS T). The excerpt tablet MS b has one further line of summary, a different catchline (rev. $22^{\prime}=E A E$ XXIII 1 ), and then a colophon. MS S concludes with a warning about the text's restricted circulation (rev. 53-4, see collations at the end of this section), a section on the divine origin of lunar eclipses that is otherwise part of $E A E$ XXII (rev. 55-7, see Rochberg-Halton 1988: 216 and 269-70), and finally a colophon (rev. 58). The colophon of MS b shows that in this recension $E A E \mathrm{XX}$ was followed by $E A E$ XXIII, the first tablet of solar-eclipse omens (Rochberg-Halton 1988: 178).

Other collations of $\S X I V$ and colophons. MS b rev. 22' (Rochberg-Halton 1988: 221): IGI.LÁ; MS S rev. 53 (p. 216): ]-ku?-un la mu-du-ú a-a i-mu-ur AN.M[I; MS T rev. 1 ff. (p. 216) duplicates MS Z 5'-15': 1': ] 'AN'.[MI; 4': ša]r? KUR gu-t[i-i; 6': ] LÚ.Úš ul i[q-qeb-bir; 7': ] 'ZZI' KÚR ana [; MS Y rev. $22^{\prime}$ (p. 218): GI]M SUMUN IGI.KÁR [.

\section{Conclusions}

Jerrold Cooper has recently discussed the terminology that cuneiformists use to describe the texts they edit, and has proposed definitions for use when describing the variant traditions in which the text of a composition is handed down. He makes a useful distinction between "version" and "recension", defining them as follows (Cooper 2005: 50):

recension - a manuscript or group of manuscripts whose text shows significant but minor variations from other manuscripts of a given literary composition

version - a manuscript or group of manuscripts whose text shows significant and major variations from other manuscripts of a given literary composition

Cooper also comments, in applying the proposed terminology to Sumerian literary compositions, that the "choice of the label 'version' or 'recension' may be subjective, but most Sumerologists would agree most of the time on the choice of one or the other in any given case" (Cooper 2005: 50). He cites the two poems of Gilgameš in the Cedar Forest as examples of a composition in two distinct versions, while the Old Babylonian and first-millennium texts of Angimdimma are so close that in his opinion they can be described as different recensions of the same version.

Francesca Rochberg discusses the older compilations of lunar-eclipse omens that are ancestral to the developed form of $E A E$, referring to the Old Babylonian texts as "prototypes or forerunners" and to the late second-millennium compilations as "transitional texts" (Rochberg-Halton 1988: 19-25); she also speaks of the first-millennium text as the "final' version" (Rochberg 1999: 418). U1la Koch-Westenholz has already written about the mid-second-millennium lunar-eclipse omens as evidence for a " "proto'-version of the canonical series $E A E$ " (Koch-Westenholz 1993: 235). She noted also that the distinctive mythological paragraphs of $E A E$ I and XXII were already associated with lunar omens at Hattusa and Emar (Koch-Westenholz 1993: 236). That being so, it is safe now to use Cooper's terminology and refer to the second-millennium "forerunners" simply as Old and Middle Babylonian "versions" of $E A E$.

It has long been known that in the first millennium there was no single textus receptus of $E A E$ (see already Weidner 1941-4: 181). In respect to the sources Rochberg used in reconstructing the lunar-eclipse omens she was surely correct to use the term "recension", for while there is much minor variation to be observed in them, there are few major differences. Her identification of two recensions found the division between them broadly reflected in script, with most manuscripts of her Recension A exhibiting Assyrian script and most manuscripts of Recension B, Babylonian hands (Rochberg-Halton 1988: 174). The study of the text conducted above suggests a more complex state of affairs. The sources can first be sorted into distinct groupings by period. Three such groupings are immediately visible: 
(i) MS Y from the temple of Aššur at Aššur, which is the only extant Middle Assyrian manuscript of $E A E \mathrm{XX}$ in its familiar, developed form,

(ii) MS S, an early Neo-Babylonian manuscript claiming to be a lineal descendant, as it were, of an eleventh-century text, and those later sources that exhibit the same text, i.e. NeoBabylonian MSS $U$ and $b$ from Babylon, which are themselves most probably parts of one exemplar, and

(iii) the many manuscripts and smaller numbers of excerpt tablets and commentaries of the seventh to third centuries, represented in the latter half of $E A E \mathrm{XX}$ by Neo-Assyrian MSS $\mathrm{C}, \mathrm{D}, \mathrm{N}, \mathrm{f}$ (all Kuyunjik), $\mathrm{M}$ (Nimrud) and $\mathrm{P}+\mathrm{Q}$ and $\mathrm{Z}$ (both Aššur), Neo-Babylonian MSS L and T (both Kuyunjik), R (Uruk), a (Babylon) and e (Ur), and Late Babylonian commentaries MS k and Uruk IV 162 (both Uruk).

These three groupings of manuscript are witness to the developed version of $E A E$ (as opposed to the much shorter earlier versions) at three different points in its history. There were at least two recensions of $E A E$ current at the end of the second millennium, represented by the manuscripts of groupings (i) and (ii). The texts of the tablets in these two groupings are similar enough to speak of them as two closely related but distinct recensions, and it seems appropriate to call them respectively the Middle Assyrian recension and the Middle Babylonian recension of the developed version of $E A E$. That they fail to match is only to be expected: the mid-to-late second millennium was a time when many literary works circulated in widely variant editions, and distinctive textual traditions occur on Middle Assyrian manuscripts from Aššur even in relatively stable compositions like Lugale and Angimdimma (Geller 1990: 211). The Middle Babylonian recension of EAE XX, essentially MS S with MSS U and b, is roughly the same as Rochberg's Recension B - she included those same manuscripts together with others that are not witnesses of $\S$ VII ff. (MSS V, W and X), and also MS T (on which see below). As she noted, these are all in Babylonian script and either from Nineveh (Kuyunjik) or Babylon; they show that this Middle Babylonian recension continued to be copied deep into the first millennium.

The manuscripts grouped under (iii) present a text of $E A E \mathrm{XX}$ that is essentially standardized in order and content but far from uniform in every detail. We have seen that Late Babylonian MS IM is close to Neo-Assyrian MSS M (Nimrud), $N$ (Kuyunjik) and $P+Q$ (Aššur), in that substantive variant readings between them are few. Neo-Babylonian excerpt tablet MS e (Ur) and Neo-Assyrian excerpt tablet MS f (Kuyunjik) are also true to MS IM. We may speak of these manuscripts as MS IM and duplicates. Neo-Babylonian MS T (Kuyunjik) and Neo-Assyrian MS $\mathrm{Z}$ (Aššur) are close to MS IM and duplicates but have extra material in conclusion. Neo-Assyrian MSS C and D (both Kuyunjik) are more prone to disagreement with MS IM and duplicates; they do not overlap, so cannot be judged one against the other. Neo-Babylonian MS L (Kuyunjik) is too fragmentary to ascribe to one or other recension with any confidence; Neo-Babylonian MS $\mathrm{R}$ (Uruk) is also very meagre but clearly treads a lonely path of its own. Neo-Babylonian MS a (Babylon) and the Hellenistic commentaries from Uruk are mostly faithful to MS IM and duplicates but sometimes diverge from them; the recent date of the commentaries suggests that the text continued to evolve even in the late first millennium. This is also the conclusion that Hermann Hunger came to in editing a commentary on $E A E$ VIII from the same provenance as Uruk IV 162 (Hunger 1995). In short, the extant tablets gathered under grouping (iii) do not speak for a monolithic third recension (i.e. Rochberg's Recension A) but for a cluster of parallel and partly contemporaneous editions that we may call the first-millennium recensions of $E A E$.

The recovery of Late Babylonian MS IM from the Sippar Library has made it possible to sharpen understanding of the recensional differences in first-millennium manuscripts of $E A E \mathrm{XX}$ and the text's continuing development in the Late Babylonian period. It remains to say something about the prior evolution of the text. The production of the developed version of $E A E$, in its several recensions, from the various older Middle Babylonian versions has been attributed to "Kassite period transcribers and editors" (Rochberg-Halton 1984: 127, similarly Rochberg 1999), for this was a time when literary compositions and, especially, omen anthologies, began to be organized into standardized texts. The relationship between these late-second millennium versions of $E A E$ and the still-unpublished Old Babylonian version has been set out by Rochberg (1999: 416-19). 
Here we may add that what we have identified as a Middle Babylonian recension of the developed version of $E A E$, essentially early Neo-Babylonian MS S and later duplicates, offers intriguing evidence of how the developed version evolved. Curiously sandwiched between the protasis and apodosis of the lunar-eclipse omens of $\$$ II-VI, VIII-X and XII of this recension occur additional lunar-eclipse omens that consist of an abbreviated protasis and brief apodotic phrases. These shorter omens are not always easily identified in Rochberg-Halton's edition, where some of them have been misunderstood. Those of $\S$ VIII-X and XII have already been given in the commentary above; the remainder are presented here in collated transliterations:

\author{
$\S \mathrm{II}$

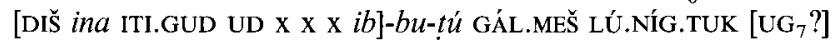 \\ MS S obv. 30 (cf. Rochberg-Halton 1988: 188) \\ [ $($ (If) in Ayyaru, (on) a day ... (the moon god brings about an eclipse):] there will be starvation; a rich \\ man [will die(?).]
}

[DIŠ ina ITI.SIG $_{4}$ UD MIN] ILLU KIŠ GIN-kam dišKUR BURU ${ }_{14}$ RA-iș ÉRIN.Ḣ́ ma-'-[du imaqqut(?)]

MSS S obv. 38-9// Uं obv. 11' (cf. Rochberg-Halton 1988: 192)

[ (If) in Simanu, (on) a day ditto, (the moon god brings about an eclipse):] an inundation of abnormal surge will come, Adad will trample crops, many people [will perish(?).]

$\S \mathrm{IV}$

[DIŠ ina ITI.ŠU UD] MIN $i b$-bu-tú ib-ba-aš-š[ $[i \ldots] / /$ ina ITI.ŠU ina la mi-na-ti-šu ub-bu-túu GÁL.MEŠ LÚ.NíG.TUK $\mathrm{UG}_{7}$ URU.DIDLI ZẢU.MES̆

MSS S obv. 51 // U obv. 19' (cf. Rochberg-Halton 1988: 195) [ๆ (If) in Dumuzi, (on) a day] ditto (var.: unpredictably in Dumuzi), (the moon god brings about an eclipse): there will be starvation, a rich man will die, settlements will disappear.

$\S \mathrm{V}$

DIš ina ITI.NE 'UD MIN' \{ras.\} A.ZI.GA ina ÍD GIN BURU ${ }_{14}$ ina KUR SI.S[Á ... ] // ina ITI.NE AN.MI ina la mi$n a-t i-s \breve{u}$ ILLU ina ÍD GIN-kam BURU ${ }_{14}$ KUR SI.SÁ LÚ K[1 LÚ $\left.u l\right] i-d a-a b-b u-u b$

MSS S obv. 59 // U rev. 4-5 (cf. Rochberg-Halton 1988: 198)

I (If) in Abu, (on) a day ditto (var.: unpredictably in Abu), (the moon god brings about) an eclipse: an inundation will come down the river, the harvest of the land will be successful, [no] man will sue [another.]

$\S \mathrm{VI}$

DIŠ ina ITI.KIN MIN bar-tum ÉRIN $m a-a{ }^{\prime}-d u$ ŠUB- $u t$ LU[GAL $\ldots$ ] / ina IT[I.KIN ... ]

MSS S obv. 69 // U rev. 13 (cf. Rochberg-Halton 1988: 201-2)

I ( If ) in Ulūlu ditto: rebellion, many people will perish, the king [ $(\ldots)]$

The protases of these omens are calendrical, fixing eclipses by month and day. The abbreviation UD MIN "day ditto" occurs in MS S up to $\S \mathrm{V}$, but is then further reduced to MIN "ditto" in $\S \mathrm{VI}$ ff. The full notation signified by these two abbreviations is lost in the lacuna at obv. 30 (§II). Given that the extra omens are embedded in portents of the fourteenth day, one might have expected "day ditto" to signify UD.14.KAM. However, where it is preserved, the later source for the same recension of $E A E \mathrm{XX}$ has instead ina la minâtǐš "not at its predicted time" (MS U $\S \S \mathrm{IV}-\mathrm{V})$. Elsewhere in the lunar-eclipse omens this phrase and its synonym, ina lā adannišu "at the wrong time", denote eclipses that take observers by surprise by occurring early or late, on days outside the time when they were expected (Rochberg-Halton 1988: 42, Koch-Westenholz 1993: 236). Unpredictable eclipses are not a concern of the Old Babylonian lunar-eclipse omens described by Rochberg (Rochberg-Halton 1988: 19-22, Rochberg 2006), but they do appear in texts of the later second millennium. They are one of the topics of the lunar-eclipse omens from Emar, of a broken Middle Assyrian tablet, BM 121034, and of the fragmentary EAE XVII-XVIII. Close parallels to most of the extra omens of $E A E \mathrm{XX}$ can be found in all three texts:

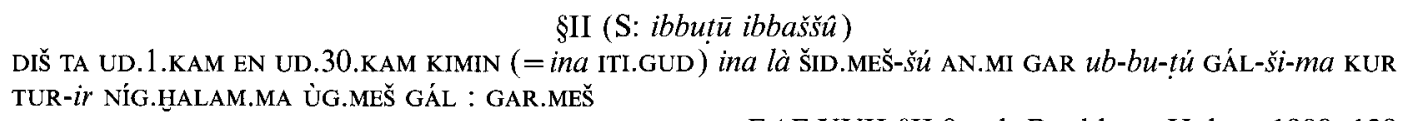

EAE XVII §II.9, ed. Rochberg-Halton 1988: 128 I (If) from the first to thirtieth day (or if) unpredictably in Ayyaru (the moon god) brings about an eclipse: there will be starvation and the population will dwindle; a catastrophe will happen (var. occur) to the people. 
DIŠ ina ITI.ŠU ina la ŠID.MEŠ-šú AN.MI GAR ŠÀ.GAR GAR

$\S \mathrm{IV}(\mathrm{S} / / \mathrm{U:} \mathrm{ibbutu} \mathrm{ibbašši)}$

EAE XVII §IV.11, ed. Rochberg-Halton 1988: 131 I (If) unpredictably in Dumuzi (the moon god) brings about an eclipse: famine will occur.

$\S \mathrm{V}$ (S // U: mīlu ina nāri illaka)

[DIš ina ITI.NE] ina la mi-na-ti-šú AN.MI GAR ILLU ina íD GIN-kam

EAE XVII §V.11, ed. Rochberg-Halton 1988: 132

[ 9 (If )] unpredictably [in Abu] (the moon god) brings about an eclipse: an inundation will come down the river.

MIN ( = DIš ina ITI.NE.NE.GAR) [ina la a-d]a-ni-šu KIMIN (=attalû) GAR mi-lu ina ÍD i-sa-dar Emar VI 652 28, ed. Arnaud 1987: 261

If (If) in Abu an eclipse occurs [at the wrong] time: inundation in the river will be regular.

§VI (S // U: bārtu șābu ma'du imaqqut)

[DIŠ ina ITI.KIN ina la ŠID.MEŠšrú] AN.MI GAR HुI.GAR.MEŠ [ . . ]

$E A E$ XVII §VI.12, ed. Rochberg-Halton 1988: 134

[I (If) unpredictably in Ulūlu] (the moon god) brings about an eclipse: rebellions [ . . . ]

MIN (= DIŠ ina ITI.KIN. ${ }^{d}$ INANNA) [ina la $\left.a-d\right] a-n i-\check{s} u$ KIMIN (=attalû iššakin) bar-tum ana LUGAL šUB ÉRIM DAGAL.LA!

Emar VI 652 34, ed. Arnaud 1987: 262

If (If) in Ulülu an eclipse occurs [at the wrong] time: rebellion against the king, downfall of numerous people.

§IX (S: Adad irahhis mīlu [illak]ma [ugāru? inn]addi mahīru isehher)

DIŠ ina ITI.GAN [ina la mi-na-ti-šú] AN.MI GAR ILLU.M[EŠ . . . ]

$E A E$ XVIII §IX.13, ed. Rochberg-Halton 1988: 148

If (If ) [unpredictably] in Kislimu (the moon god) brings about an eclipse: inundations [ . . ]

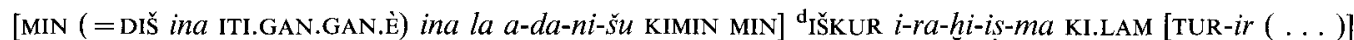

Emar VI 652 51', ed. Arnaud 1987: 262

[ ( If) in Kislimu an eclipse occurs at the wrong time:] Adad will rampage and commerce [will dwindle $(\ldots)]$

§XII (S // b: ibbutū ibbašš̂̀ sạabu ma'du imaqqut mah̄iru isehher niš̄u šerrīšina ana kaspi ipaššarā) [MIN (= DIŠ ina ITI.ŠE.KIN.KUD) ina la $a$-da-ni-šu] KIMIN MIN $u b$-bu-țú GAR ÉRIM $\left[m a\right.$ - $\left.^{\prime}-d\right] u$ ú?-X $\left[\ldots{ }^{73^{\prime}} \ldots\right.$ ÙG.MEŠ L]Ú.TUR!?-ši-na ana KÙ.BABBAR [BÚR-ra]

Emar VI 652 72'-3', cf. Arnaud 1987: 263

[ (If) in Addaru] an eclipse occurs [at the wrong time:] there will be starvation, many people will [ . ., people will sell] their babies for silver.

[DIš ...-m] $a$ GAR $u b$-bu-ț $u$ GAR.MEŠ UD [x (x) x]

BM 121034 rev. 11', coll., ed. Rochberg-Halton 1988: 276-7

[ (If ) in Addaru the moon god ... ] and brings about [an eclipse at the wrong time (or unpredictably):] there will be starvation, ... [ [..]

These apodoses reveal that lunar eclipses occurring at unexpected times were almost always held to portend economic collapse, famine and widespread mortality. This outcome is explicitly stated in the introduction to the Middle Babylonian recension of $E A E \mathrm{XX}$, which states as a general principle: "I (If the moon god) brings about an eclipse unpredictably: [there will be] starvation [ . . . ]" (MSS V 5: DIš ina la mi-na-ti-š[u// S obv. 5: ] la mi-na-ti-̌sú AN.MI GAR $i b-b u-$ túu [ibbǎšrûu :.. ] // X 3': GA]R ub-bu-tu [, coll.).

By contrast to the wealth of parallels collected above, only one good match for the extra omens of MS S can be found by searching the apodoses attached in early texts to an eclipse on the fourteenth day of the respective month. It occurs in the unpublished Old Babylonian lunareclipse omens:

§VI (S // U: bārtu șābu ma'du imaqqut)

[AN.TA].LÙ ITI.KIN. ${ }^{\mathrm{d}}$ INANNA UD.14.KAM GAR ba-ar-tum $a$-na LUGAL ÉRIN [rapšu] $i$-ma-qú-ut // BE ITI.KIN.

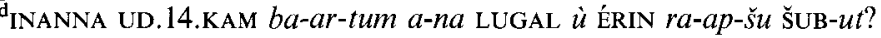

BM 22696: 38 // BM 86381: 40

If on 14th Ulūlu (the moon god) brings about an eclipse: rebellion against the king, numerous people will perish.

The parallel apodoses for unexpected observations in early versions of calendrical lunar-eclipse omens far outnumber the single parallel for the fourteenth day. This makes it unlikely that in the extra omens of MS S the signs UD MIN (or just MIN) stand for UD.14.KAM and confirms the 
correctness of MS U. The reading of UD is obviously some part of $\bar{u} m u$ "day" and the whole phrase surely signified the same as MS U's ina la minât $\bar{s} \breve{s} u$ : read perhaps $\bar{u}$ m lä minâtǐš "(on) an unpredicted day" or $\bar{u} m$ lā adannišu "(on) the wrong day".

The apodoses employed in the omens of unpredictable eclipses in $E A E \mathrm{XX}$ are markedly different from the pseudo-historical predictions that otherwise characterize this tablet, which begin ina libbi (ana) GN purussû nadin "(therein) a prediction is given for GN". As is clearly seen in the passages just quoted, they are typical of the apodoses attached to the lunar-eclipse omens in other first-millennium tablets of $E A E$ and in older versions of the lunar-eclipse omens. The fact that variants of them occur in $E A E$ XVII-XVIII is good evidence of an old pedigree, for this part of the series was founded on Old Babylonian material (Rochberg 2004: 70, 2006: 344-5). Matches with the Emar and Middle Assyrian texts are also suggestive, because these are even more closely related to the Old Babylonian eclipse omens. Accordingly, it seems likely that the omens of unpredictable eclipses in the developed text of $E A E \mathrm{XX}$ are a residue of $E A E$ in some earlier version. They certainly call into question Rochberg's assertion that "Tablet 20 is the only eclipse tablet that has no connection to the Old Babylonian material" (2006: 346). The Middle Babylonian recension of $E A E$ represented by MSS S and $\mathrm{U}$ is thus highly important for the textual history of $E A E$, for it is a legacy of the moment that the pseudo-historical apodoses began to displace the traditional Old Babylonian apodoses. The embedded omens of unpredictable eclipses show it all the more clearly to be an intermediary between the second-millennium versions of $E A E$ and the developed version known from first-millennium recensions.

In considering the history of $E A E$, Rochberg gives an account of the Babylonians' own traditions. One such tradition was that $E A E$ was handed down by the god Ea himself, as recorded in a NeoAssyrian catalogue of literary and scholarly compositions (Lambert 1962: 64-5 I 1; Rochberg 1999: 419, 2004: 181). Another tradition reported that $E A E$ was among the divinatory expertise revealed to the scholarly communities of Nippur, Sippar and Babylon by Enmeduranki, a legendary king of Sippar before the flood, who was educated in these things by the gods of divination, Šamaš and Adad (Lambert 1967, 1998, Rochberg 1999: 421, 2004: 183). As Rochberg rightly explains, these two traditions "are not making a theological claim ... [but] simply attribute to the text the most ancient origin possible" (Rochberg-Halton 1984: 137).

There is other native evidence that is not everywhere acknowledged. The Babylonians knew a third, less mythological, tradition about the early history of $E A E$, which held that it was one of the many scholarly compositions associated with the name of Esangil-kin-apli. This individual was a prominent scholar of Borsippa contemporary with Adad-apla-iddina, king of Babylon in the eleventh century. The association of $E A E$ with him (observed long ago by Lambert 1962: 69) is reported in the first-millennium catalogue known as the Exorcist's Manual (Geller 2000: 242-54), where the series' ancient title (1. 39: ud-an- ${ }^{\mathrm{d}}$ en.líl.lá) is included among other compositions under

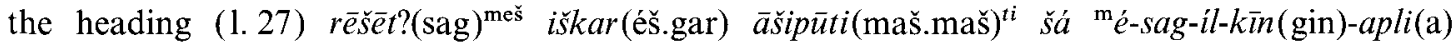
"incipits of series of exorcists' lore of Esangil-kīn-apli". Two newly available Late Babylonian manuscripts of the Exorcist's Manual bestow on Esangil-kin-apli an anachronistic patronym and elaborate titulary: "son of Asalluhe-mansum (= Marduk-iddinam?), sage of King Hammurapi of Babylon, descendant of the goddess Lisin, purification priest of Ezida". These abbreviate the longer list of honours appended to his name in first-millennium catalogues of the incipits of Sakikkü (Finkel 1988: 148-50) and reaffirm the prestige attached to him as a scholar and authority. These titles are without parallel; clearly he was a scholar of enormous distinction.

The editorial activities of Esangil-kinn-apli are well known in connection with $S a k i k k \bar{u}$, the series of diagnostic and prognostic omens (Finkel 1988); among the other texts associated with this scholar, listed in 11. 28-42 of the Exorcist's Manual, are many other medical and exorcistic series, but also the terrestrial omen series Šumma ālu. By the compiler of the Exorcists's Manual, at least, omen texts like $E A E$ and $\breve{S} u m m a \bar{a} l u$ were considered part of the tradition that exorcists had to master. Among the other texts attributed in the Neo-Assyrian catalogue of texts and authors to the god Ea are scholarly and learned compositions like Lugale and Angimdimma. Some have speculated that their attribution to the god Ea really signifies the Borsippan scholar's responsibility for these also (Geller 1990: 212-13). However that may be, there is no reason to mistrust the tradition of the Exorcist's Manual that associates $E A E$ with Esangil-kin-apli. As with 
Sin-lèqi-unninni and the Gilgamesh epic, the role of Esangil-kīn-apli in the history of $E A E$ and

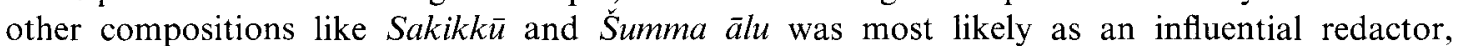
remembered to have been the key agent in establishing a text that after him served as the standard version. And as in the case of Gilgameš and other compositions with a similar history, the moreor-less stabilized version of $E A E$ that was written down in its various recensions in first-millennium scribal centres can appropriately be called the Standard Babylonian version.

The text of EAE XX emerges from this study as an extraordinary collation of heterogeneous material. It consists principally of thirteen calendrical omens from lunar eclipses observed on the fourteenth day, two for the first month and one each for the other eleven ( $\S I-X I I)$, and a section of summary ( $(\mathrm{XIII})$. In a curious editorial technique, one Middle Babylonian recension (MS S etc.) interrupts nine of the lunar-eclipse omens by interposing between protasis and apodosis brief calendrical omens of extraneous origin for eclipses on another day (\$\$II-VI, VIII-X and XII). The same recension also appends to the apodosis of the omen for the eleventh month a related but non-calendrical eclipse omen, perhaps as a gloss (§XI). As if to underscore the eclectic nature of the tablet, it and a Middle Assyrian recension (MS Y) introduce the tablet with a schematic passage that sets out in general terms the import of different directions of eclipse for the four nations of the world (\$I "Intro." in Rochberg's edition). Both recensions also conclude with two omens of the Yoke star that have nothing to do with lunar eclipses ( $§ I V$, above). This extraneous material is absent from most of the other recensions current in the first millennium and was perhaps deliberately excluded as superfluous, but homogeneity was never completely achieved. In all the late recensions, as in the older ones, three of the main lunar-eclipse omens are supplemented with celestial omens concerning the movements of fixed stars ( $\$$ VII and XII), and the planet Venus and the moon (§VIII). These were no doubt drawn from other parts of $E A E$ but it is odd to find them embedded in $E A E \mathrm{XX}$. It seems that the tablet never quite overcame the disorderliness that its long evolution imposed on it.

\section{Appendix. Uruk IV $162 \mathrm{obv} .1-$ rev. 2'}

Our understanding of the Late Babylonian commentary Uruk IV 162 has benefited greatly from the results of a collation undertaken by Frances Reynolds in 1998. The whole of the collated text of rev. 3'-end has been incorporated in the appropriate places of commentary above. Because the original tablet is at present inaccessible, it seems sensible to present here a transliteration of the balance also, incorporating the results of Reynolds's reading of the original tablet.

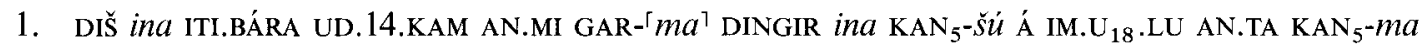

2. Á IM.SI.SÁ KI.TA $i z-k u$ : ina UGU re-eš ši-kin qa-bi: taš-ri-tum

3. e-la-nu : KI.TA : šap-la-nu : ina šu-ri-in-ni-šú dili-pát ana š̀̉ $30 \mathrm{KU}_{4}$

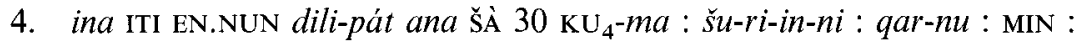

5. sal-mu šá š̀̀ 30 : šá-niš ina šu-ri-in-šú dili-pát ana š̀̀ $30 \mathbf{K U}_{4}:$ šu-ri-in-ni :

6. i-da-tum ana AN.MI : ina AN.MI dili-pát ina ÁB.LÚ.HUN.GÁ ana tar-și 30 DU-ma :

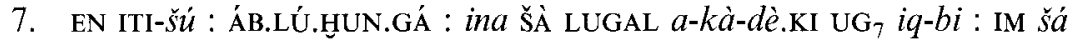

8. ina ŠU.MIN-ka tu-kal : IM šá ana KUR.KUR il-la-ku pi-šir a-na ŠÀ

9. ta-qab-bi : EŠ.BAR ana LUGAL a-kà-dè.KI ta-nam-din : ITI.BÁRA :

10. ÁB.LÚ.HUN.GÁ KUN ÁB.LÚ.HUN.GÁ : $a$-kà-dè.KI : DINGIR šá ina $\mathrm{KAN}_{5}$-šú

11. EN.NUN $U_{4}$.ZAL.LA SAR-ma 1/3.TA.ÀM EN.NUN $u h-h i-r u$ : $i n a$ EN.NUN $\mathrm{U}_{4}$.ZAL.LA

12. AN.MI GAR-ma $\mathrm{KAN}_{5}$ ŠÚ-ma : 1/3.TA.ÀM : šal-šú šá $m u$ ?-šu šá-lul-tu $u_{4}$ EN.NUN

13. šáa-niš 1/3.TA.ÀM šá iq-bu-ú : šal-šú šá SI DINGIR a-na ZÁLAG TAG TA $_{4}$

14. ad-ri ŠÚ-ma: DIŠ ina ITI.GAN UD.28.KAM SAG IGI.DU 8 .A IGI-ma dili-pát ana ŠÀ 30

15. $\mathrm{KU}_{4}$ : ina UD.NÁ.A dili-pát ana Š̀̀ $30 \mathrm{KU}_{4}-m a: 1$ me AN.MI DUG 4 .GA

16. [U]D.NÁ.A AN.MI $u ́$ !-kal-lam-ka: $u l$-tu UD.NÁ šá ITI.GAN

17. [ana?] UD AN.MI šá ITI.BÁRA ta-qab-bi: 1 me $u_{4}$-mi a-na UD.MEŠ

18. [x]-de-e-ti : ki-șir šal-šú šá ITI.BÁRA šá E-ú šá ITI.BÁRA.MIN.KAM $\breve{s} u-u$

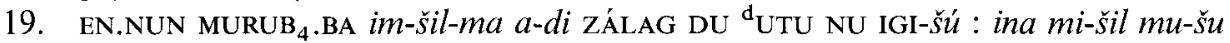

20. AN.MI SAR-ma a-di la SAG $p u-u ́-s u$ ZÁLAG-ma : EN ZÁLAG DU ${ }^{\mathrm{d}} \mathrm{UTU}$

21. NU IGI-šú a-di UGU nu-um-ri-šú pu-ú-ṣu NU IGI : šá-niš EN È 
22. ${ }^{\mathrm{d}} \mathrm{UTU}$ NU IGI-šú $a$-di la KUR ${ }^{\mathrm{d}} \mathrm{UTU}$ ZÁLAG-ma NU DÙ $: i-s ̌ a b-b i t: i-d a k-k u$

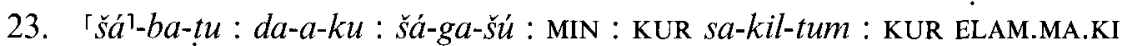

24. [ $\ldots d] a n-n u:$ LUGAL AŠ.TE GAL DAB-bat : LUGAL ELAM.MA.KI AŠ.TE : šá

25. $[\ldots$

... ]x $-m a$

rev.

$1^{\prime}$. traces

2'. he-pí DÚR : $u$-šáa-am-qa-at ta-ba-x x[ ... ]

N.B. Lines 4-6 are translated above in fn. 2, 11. 7-9 in the textual note on IM 1244851.4 , and 11. $19-20$ in the textual note on IM $12448511.2-3$.

\section{References}

Arnaud, D. 1987. Recherches au pays d'Aštata. Emar VI/4. Textes de la bibliothèque: transcriptions et traductions. Paris

Bauer, T. 1936. Eine Sammlung von Himmelsvorzeichen. Zeitschrift für Assyriologie 43: 308-14

Beaulieu, P.-A. 1999. The Babylonian man in the moon. Journal of Cuneiform Studies 51: 91-9

Brown, D. 2000. Mesopotamian Planetary Astronomy-Astrology. Cuneiform Monographs 18. Groningen

Brown, D. and M. Linssen 1997. BM $134701=1965-10-14$, 1 and the Hellenistic period eclipse ritual from Uruk. Revue d'assyriologie 91: 147-66

Charpin, D. 2004. Histoire politique du Proche-Orient amorrite (2002-1595), pp. 25-480 in D. Charpin, D. O. Edzard and M. Stol, Mesopotamien. Die altbabylonische Zeit. Orbis Biblicus et Orientalis 160/4. Fribourg and Göttingen

Cooper, J. S. 2005. Right writing: Talking about Sumerian orthography and texts. Acta Sumerologica 22 (2000) 43-52

Finkel, I. L. 1988. Adad-apla-iddina, Esagil-kīn-apli, and the series SA.GIG, pp. 143-59 in E. Leichty, Maria deJ. Ellis and Pamela Gerardi (eds.): A Scientific Humanist: Studies in Memory of Abraham Sachs. Philadelphia

Gasche, H., J. A. Armstrong, S. W. Cole and V. G. Gurzadyan 1998. Dating the Fall of Babylon: A Reappraisal of Second-Millennium Chronology. Mesopotamian History and Environment, Memoirs 4. Ghent and Chicago

Geller, M. J. 1990. Astronomy and authorship. Bulletin of the School of Oriental and African Studies 53 , 2: $209-13$

Geller, M. J. 2000. Incipits and rubrics, pp. 225-58 in A. R. George and I. L. Finkel (eds.): Wisdom, Gods and Literature. Studies in Assyriology in Honour of $W$. G. Lambert. Winona Lake

George, A. R. 1991. Review of Rochberg-Halton 1988. Orientalistische Literaturzeitung 86, 4: 378-84

Gurzadyan, V. G. 2000. On the astronomical records and Babylonian chronology. Akkadica 119-20: 177-86

Horowitz, W. 1998. Mesopotamian Cosmic Geography. Mesopotamian Civilizations 8. Winona Lake

Huber, P. J. 1987. Dating by lunar eclipse omina with speculations on the birth of omen astrology, pp. 3-13 in J. L. Berggren and B. R. Goldstein (eds.), From Ancient Omens to Statistical Mechanics: Essays on the Exact Sciences Presented to Asger Aaboe. Copenhagen

Huber, P. J. 1999-2000. Astronomical dating of Ur III and Akkad. Archiv für Orientforschung 46-7: 50-79

Huber, P. J. 2000. Astronomy and ancient chronology. Akkadica 119-20: 159-76

Hunger, H. 1995. Ein Kommentar zu Mond Omina, pp. 105-18 in M. Dietrich and O. Loretz (eds.), Vom Alten Orient zum Alten Testament. Festschrift für Wolfram Freiherr von Soden zum 85. Geburtstag am 19. Juni 1993. Alter Orient und Altes Testament 240. Münster

Hunger, H. 2000. Uses of Enūma Anu Enlil for chronology. Akkadica 119-20: 155-8

Hunger, H. 2002. Über die Bedeutungslosigkeit der Finsternisse in Enūma Anu Enlil für die Chronologie, pp. 171-6 in O. Loretz, K. A. Metzler and H. Schaudig (eds.), Ex Mesopotamia et Syria Lux. Festschrift für Manfried Dietrich zu seinem 65. Geburtstag. Alter Orient und Altes Testament 281. Münster

Hunger, H. and D. Pingree 1999. Astral Sciences in Mesopotamia. Handbuch der Orientalistik 1, 44. Leiden

Koch, J. 1998. Neues von den UR-III-Mondeklipsen. Nouvelles assyriologiques brèves et utilitaires 1998: 126-9 No. 132

Koch-Westenholz, U. 1993. Mesopotamian astrology at Hattusas, pp. 231-46 in H. D. Galter (ed.), Die Rolle der Astronomie in den Kulturen Mesopotamiens. Grazer Morgenländische Studien 3. Graz

Koch-Westenholz, U. 1995. Mesopotamian Astrology: An Introduction to Babylonian and Assyrian Celestial Divination. Copenhagen

Lambert, W. G. 1962. A catalogue of texts and authors. Journal of Cuneiform Studies 16: 59-77

Lambert, W. G. 1967. Enmeduranki and related matters. Journal of Cuneiform Studies 21: 126-38

Lambert, W. G. 1998. The qualifications of Babylonian diviners, pp. 141-58 in S. M. Maul (ed.), Festschrift für Rykle Borger zu seinem 65. Geburtstag am 24. Mai 1994. Cuneiform Monographs 10. Groningen

Reiner, E. 1999. Babylonian celestial divination, pp. 21-37 in N. M. Swerdlow (ed.), Ancient Astronomy and Celestial Divination. Cambridge, Mass. 
Rochberg, F. 1999. Continuity and change in omen literature, pp. 415-25 in B. Böck, E. Cancik-Kirschbaum and T. Richter (eds.), Munuscula Mesopotamica: Festschrift für Johannes Renger. Alter Orient und Altes Testament 267. Münster

Rochberg, F. 2004. The Heavenly Writing: Divination, Horoscopy and Astronomy in Mesopotamian Culture. Cambridge

Rochberg, F. 2006. Old Babylonian celestial divination, pp. 337-48 in A. K. Guinan et al. (eds.), If a Man Builds a Joyful House. Assyriological Studies in Honor of Erle Verdun Leichty. Cuneiform Monographs 31. Leiden

Rochberg-Halton, F. 1984. Canonicity in cuneiform texts. Journal of Cuneiform Studies 36, 2: 127-44

Rochberg-Halton, F. 1988. Aspects of Babylonian Celestial Divination: The Lunar Eclipse Tablets of Enūma Anu Enlil. Archiv für Orientforschung Beiheft 22. Horn

Schaumberger, J. 1949. Die Mondfinsternisse der Dritten Dynastie von Ur. Zeitschrift für Assyriologie 49: 50-8

Schaumberger, J. 1954-6. Astronomische Untersuchung der "historischen" Mondfinsternisse in Enûma Anu Enlil. Archiv für Orientforschung 17: 89-92

van Soldt, W. 1994. Review of J. L. Berggren and B. R. Goldstein (eds.), From Ancient Omens to Statistical Mechanics. Bibliotheca Orientalis 51, 1-2: 117-19

von Weiher, E. 1993. Uruk: spätbabylonische Texte aus dem Planquadrat U 18, Teil IV. Ausgrabungen in Uruk-Warka Endberichte 12. Mainz am Rhein

Weidner, E. 1941-4. Die astrologische Serie Enûma Anu Enlil. Archiv für Orientforschung 14: 172-95

Weidner, E. 1954-6. Die astrologische Serie Enûma Anu Enlil. Tafel 15-22: Texte über Mondfinsternisse. Archiv für Orientforschung 17: 71-92

Wiggermann, F. A. M. 2001. Ninšubur, pp. 490-500 in D. O. Edzard (ed.), Reallexikon der Assyriologie und vorderasiatischen Archäologie 9, 7-8. Berlin

Wiseman, D. J. and J. A. Black 1996. Literary Texts from the Temple of Nabû. Cuneiform Texts from Nimrud 4. [London] 